\title{
Syro-Uigurica III: \\ Enochic Material in a Christian Text from Turfan
}

\author{
MARK DICKENS*
}

University of Groningen ${ }^{1}$

Received: April 23, $2021 \bullet$ Accepted: July 7, 2021

(C) 2021 Akadémiai Kiadó, Budapest

\begin{abstract}
This article examines a fragmentary Christian text from Turfan written in Uyghur which contains an embedded Syriac magical text intended to be used for corralling a horse. After giving a transcription and translation of the Syriac passage and setting it in its literary context, including the role of amulets and other
\end{abstract}

* Corresponding Author. E-mail: dickens@ualberta.ca

1 This article draws on my participation (2008-2011) in the Christian Library of Turfan project, funded by the United Kingdom's Arts and Humanities Research Council (AHRC). I am indebted to my former project team members Peter Zieme, for his input on the Uyghur portion of the text examined here, Erica C.D. Hunter, for feedback on the terminology and historical use of amulets in the Church of the East, and Nicholas Sims-Williams for information on pharmaceutical texts. I am also exceedingly grateful to Thomas A. Carlson, for his help with deciphering the Syriac text under consideration, and to Gideon Bohak, for informing me of the Pishra de-Rabbi Hanina ben Dosa and providing me with text and translation of the crucial sentence discussed below. Thanks are also due to Aaron Butts, Vicente Dobroruka, Ralph Lee, Sergey Minov, Jan van Ginkel, Michelle Venn and Witold Witakowski, whose comments by email were helpful in sorting out information related to the Book of Enoch, especially in the Syriac and $\mathrm{Ge}^{\prime} \mathrm{ez}$ traditions. I am thankful to those who commented on a draft version of this paper posted to academia.edu, namely Shlomi Efrati, Nils Arne Pedersen, Jonathan Ben-Dov and Lin Lijuan, as well as to Simone-Christiane Raschmann for various bits of information related to Manichaean fragments in the Turfan Collection, Enrico Morano for the use of his Manichaean font and Mehmet Tezcan for tracking down copies of Turkish dictionaries otherwise inaccessible to me. Thanks too to Amina Elbendary and Wadie Aboul Lif for assistance with decipherment of Arabic, to Ruth Eppele Dickens and Melody Everest for helpful feedback on the overall article, and to the anonymous reviewers for their corrections and suggestions. Finally, I am grateful to the Staatsbibliothek zu Berlin - Preussischer Kulturbesitz and the Berlin-Brandenburgische Akademie der Wissenschaften for access to and permission to reproduce images of the relevant fragments. All images are copyright Depositum der BERLIN-BRANDENBURGISCHEN AKADEMIE DER WISSENSCHAFTEN in der STAATSBIBLIOTHEK ZU BERLIN - Preussischer Kulturbesitz, Orientabteilung. 
magical texts in the history of Syriac Christianity, the article discusses the angelic name Saraqael found in the Syriac extract, in an effort to trace the origins of the text. Excurses are given on the book of I Enoch and the Book of Giants, the first because the angelic name is found in it, the second because of its connections with the Aramaic and Central Asian cultural zones. The article then examines another text where the angelic name occurs, the Pishra de-Rabbi Hanina ben Dosa, before discussing possible links to other Syriac amulets and incantation bowls.

\section{KEYWORDS}

Turfan, Syriac, Uyghur, magical texts, angels, I Enoch, Book of Giants

\section{INTRODUCTION}

The Turfan Collection in Berlin consists of approximately 40,000 manuscript fragments in twenty-two languages and more than twenty scripts brought back by the four Prussian Turfan expeditions (1902-1914) (Berlin-Brandenburg Academy of Sciences and Humanities 2007: 9). ${ }^{2}$ The collection is primarily made up of Buddhist and Manichaean texts, reflecting the important role that these two religions played in Turfan during the Uyghur Kingdom of Qocho. This polity was established in the mid-ninth century after the overthrow of the Uyghur Empire by the Kyrgyz (840) and it lasted into the fourteenth century, albeit under Mongol rule after submission to Chinggis Khan in 1209. In addition to the many Buddhist and Manichaean manuscript fragments contained in the collection, there is also a rich treasure trove of just under 1100 Christian manuscript fragments in Syriac, Sogdian, Uyghur, Pahlavi (Middle Persian) and New Persian. ${ }^{3}$ The text examined in this article, signature number U 328 (T III Kurutka 1853), is one of several extant Uyghur Christian fragments providing evidence of the interaction between Syriac, the liturgical language of the Church of the East, ${ }^{4}$ and Uyghur, the lingua franca of the Turfan oasis. ${ }^{5}$

\footnotetext{
${ }^{2}$ The collection is housed in three repositories: the Staatsbibliothek zu Berlin, the Berlin-Brandenburgische Akademie der Wissenschaften, and the Museum für Asiatische Kunst (formerly Museum für Indische Kunst).

${ }^{3}$ As Dickens 2013a: 5 notes, 'the total number of Christian fragments is 1092' (for an explanation of the breakdown of numbers, see that source, also reproduced in Dickens 2020: 193). The majority of these Christian texts were catalogued for the first time by the aforementioned AHRC research project and can be found in Hunter and Dickens 2014; Sims-Williams 2012 and Zieme 2015. The few Christian fragments in Sogdian script are included in Reck 2018; those in Uyghur script can be found in three catalogues: Raschmann 2007; Raschmann 2009; Raschmann and Sertkaya 2016.

${ }^{4}$ On the general history of the Church of the East in Central Asia, see Dickens 2018.

${ }^{5} \mathrm{U} 328$ appears as Text K in Zieme 2015: 113-117 and as item No. 29 in Appendix XV of Hunter and Dickens 2014. This article is the third in a series of articles looking at interactions between Syriac and Uyghur. 'SyroUigurica I' and 'Syro-Uigurica II' have been published as Dickens and Zieme 2014 and Dickens 2013b, respectively. For an overview of multilingual Christian fragments from Turfan, see Dickens 2009a and for various aspects of the scribal culture of the Christian community in Turfan, see Dickens 2013a.
} 


\section{DESCRIPTION AND DISCUSSION OF THE FOLIO}

U 328 actually consists of two double-sided fragments - an upper one and a lower one - likely from separate folios of the same manuscript, glassed together as if they were from the same folio. ${ }^{6}$ The upper (larger) fragment is generally intact (measuring roughly $11 \mathrm{~cm}$ high by $12 \mathrm{~cm}$ wide), but most of the lower (smaller) fragment is missing; only a few words on each line of this fragment are visible, along with the inner margin. Based on the location of this margin, Peter Zieme (2015: 113) has determined that the recto of the smaller fragment appears on the same side as the verso of the larger fragment.

The text on both fragments comes from the same scribal hand and is written in black ink in Syriac Estrangelo script, clearly indicating its Christian origin. ${ }^{7}$ With the exception of a short Syriac passage which is the feature of this article, the text is entirely in Uyghur. The first eleven to twelve lines of the recto and the first nine to ten lines of the verso are relatively easy to read, despite a few lacunae. There are no rubrics, illustrations or other notable features.

As Zieme notes, the lower fragment contains the remnants of recipes for the treatment of ulcers (Uyghur $\operatorname{ti} \mathrm{s} \mathrm{kart}^{8}$ ) and other diseases, whereas the upper fragment is a mixture of several different short texts. The upper recto side (Fig. 1) begins part way through a list of the days of the month, with the positive or negative effects of each described. This is followed by pharmaceutical recipes for treating various diseases, including irאolo or sar 'when a person's head is bald.'

We might note here a similar concern for hair loss and hair growth in another Christian text from Turfan. SyrHT 1, a small fragment in Syriac published by Miklós Maróth (1984), is from a pharmaceutical recipe book; the fragment 'includes various treatments to prevent hair loss or to thwart hair growth' (Hunter and Dickens 2014: 16). ${ }^{9}$ A recipe to prevent unwanted hair from sprouting ( a "Tie up five ${ }^{10}$ bats in a strip of linen cloth and then pour in one dram of saltpeter. And when you go to the baths, daub it on the place that you wish and wash in cold water'11 or sox dis ז

\footnotetext{
${ }^{6}$ With the exception of a few texts which were not able to be glassed due to extant bindings (e.g. SyrHT 71, SyrHT 72, SyrHT 221, MIK III 45, U 338), all Christian manuscript fragments from Turfan were placed between glass plates to preserve them after they were brought back to Berlin.

${ }_{7}$ Literature in the Syriac script has been exclusively Christian since about the fourth century (prior to that, there are examples of pagan writing in Syriac, notably tomb inscriptions). The majority of Christian manuscripts from Turfan (including nearly all Syriac, most Christian Sogdian and many Christian Uyghur texts) are written in Estrangelo, the most basic version of the Syriac script. Other religious communities at Turfan would have used other scripts, but never the Syriac script.

${ }^{8}$ All readings of the Syriac script on U 328 have been taken from digital images of the manuscript fragment(s) and compared with the published text in Zieme 2015.

9 In the process of writing this article, I was made aware of the recent publication of Lin 2020, an excellent article on this fragment and an adjoining one (SyrHT 388).

${ }_{10}$ The symbol that looks like the Syriac letter $>$ (which would represent the number 70) is in fact the Aramaic symbol for the number five, which looks very similar to Syriac $ح$. As Nicholas Sims-Williams, to whom I am indebted for this information, notes it is characteristic of Syriac pharmacological texts to use the ancient Aramaic numeral symbols' (personal correspondence, July 28, 2020). See Budge 1913: 525 for a table of these symbols.

${ }^{11}$ My reading from the digital image of SyrHT 1. See also Sims-Williams 2011: 363. By contrast, Maróth 1984: 120 interprets $ح$ as an abbreviation for a plant name involving the element حمَi 'root, plant, shoot.'
} 


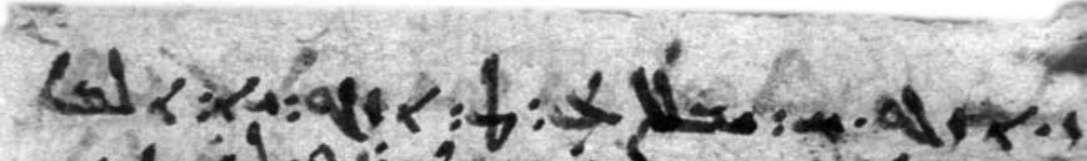

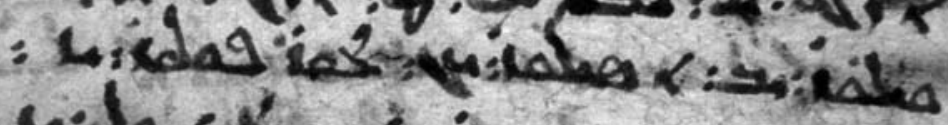

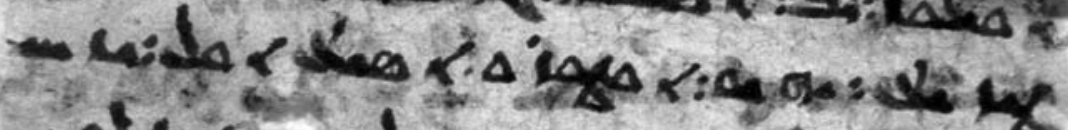

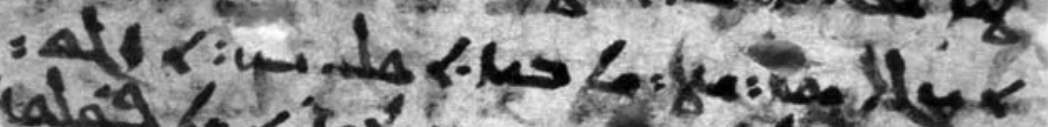
inas for tos?

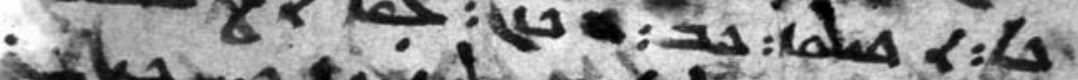

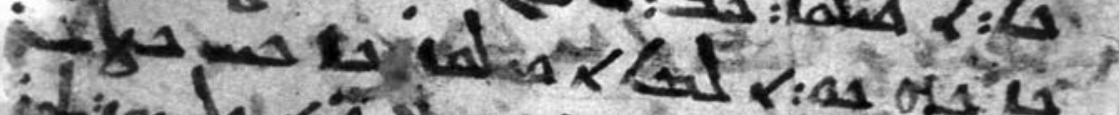

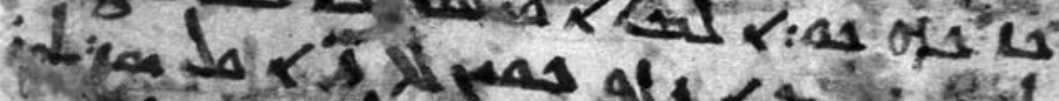

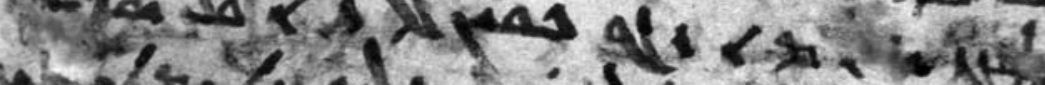

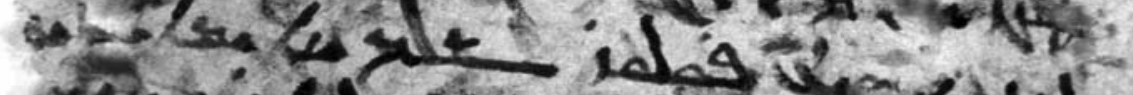

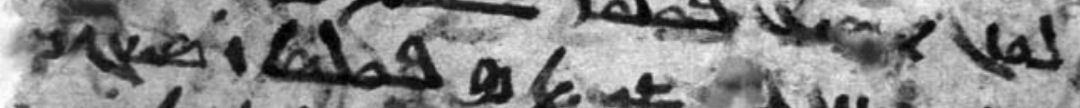

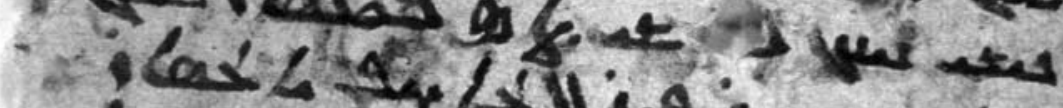

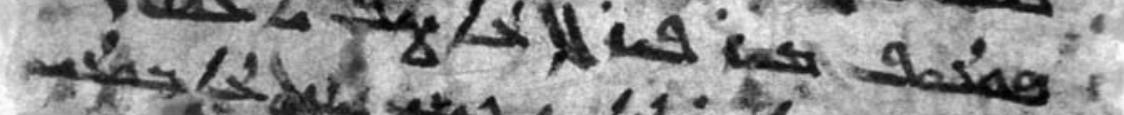

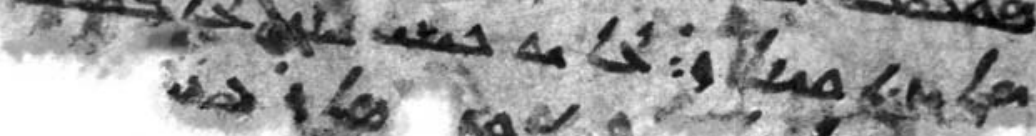

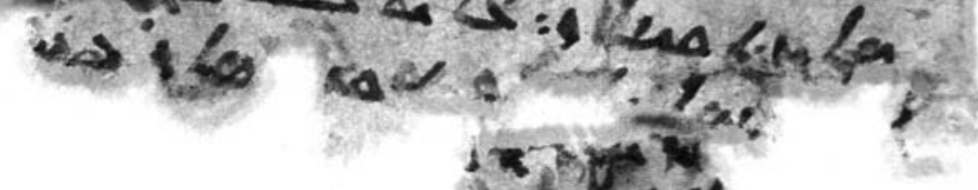

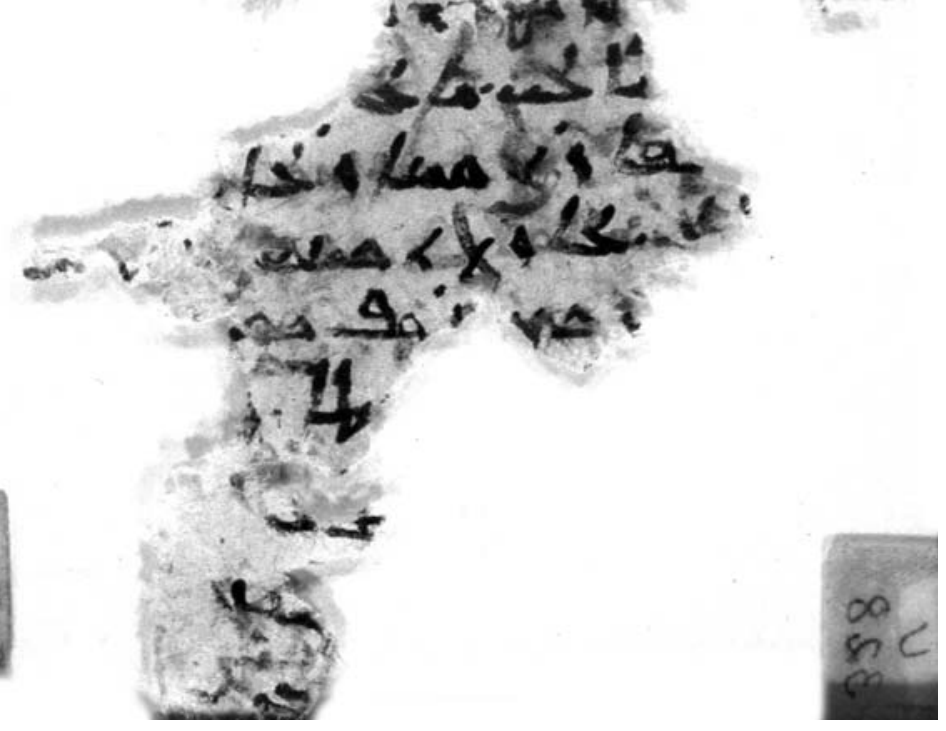

Fig. 1 U328 recto

( 


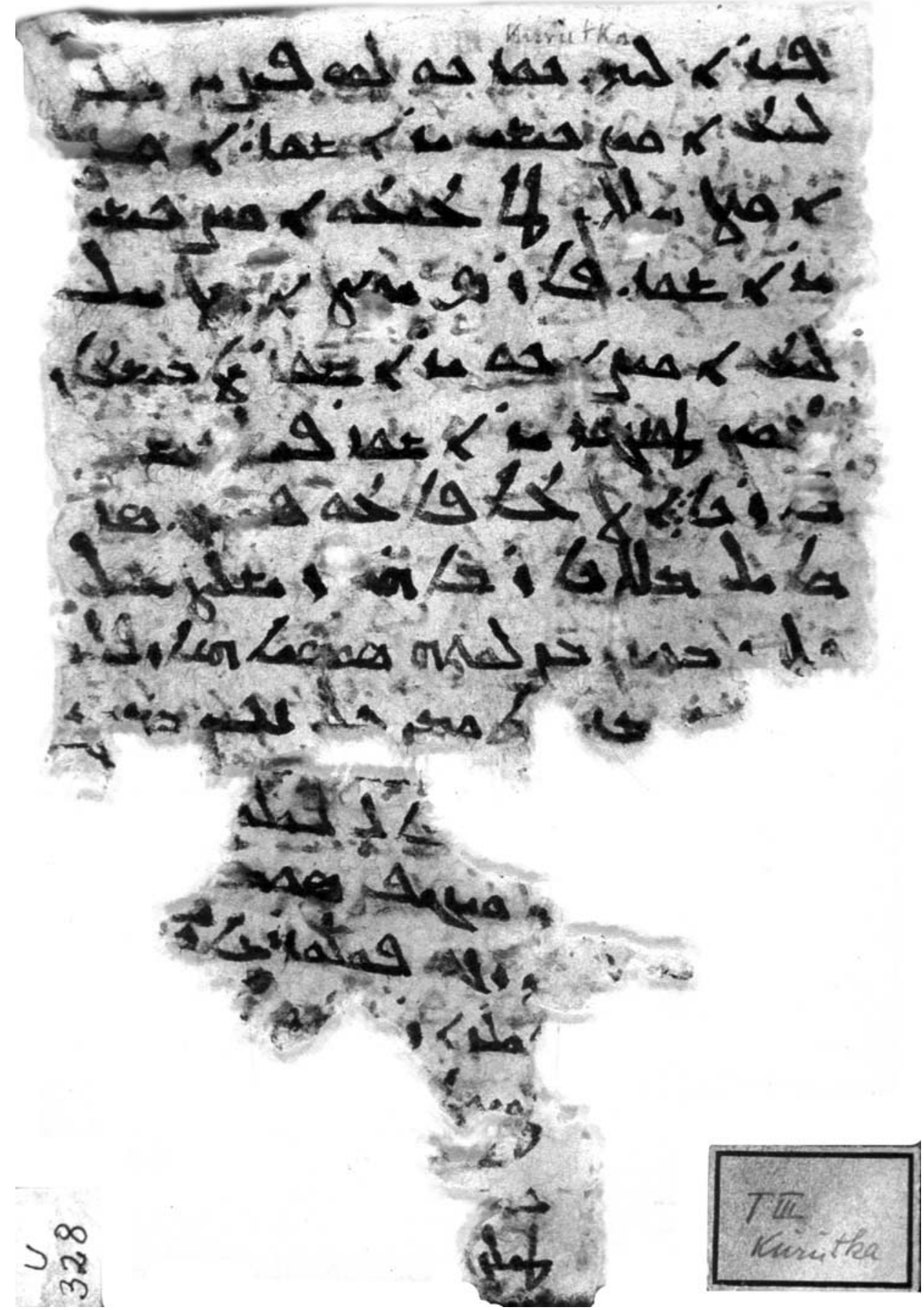

Fig. 2 U328 verso 
and daub' (Hunter and Dickens 2014: 16). Another pharmacological text from Turfan, written in New Persian in Syriac script and extant in two fragments (M 7340 and n 175) has been published by Nicholas Sims-Williams (2011: 361-367; 2013). Although it does not contain any remedies related to hair, it nonetheless indicates an interest on the part of Turfan Christians in pharmaceutical matters. It is interesting and perhaps significant that all three texts under consideration - whether Syriac, New Persian or Uyghur - were written in the Syriac script.

Returning to U 328, lines 1-7 of the upper verso side (Fig. 2) contain a sort of horoscope intended to match people based on their birth year in the twelve-year animal cycle calendar used by the Turks (and Chinese). This section is followed by the Syriac passage that will be focussed on below. Zieme (2002) initially published the short horoscope section in an article discussing 'twitching texts' amongst Turkic peoples. These belong to the general category of divination or omen texts and are concerned with foretelling the future based on bodily twitches and jerks. Although $\mathrm{U} 328$ does not mention twitching, the link between twitching and the animal cycle can be found in another Uyghur text from Turfan contained in the fragments $\mathrm{Ch} / \mathrm{U} 6796+\mathrm{Ch} / \mathrm{U}$ 6238. As Zieme (2002: 388-390) suggests, the references to the animal years suiting certain types of people in U 328 may have been used to determine whether one person was suitable for marrying another. I include here the Uyghur text (in Syriac script and in transcription), along with an English translation of this section (verso, lines 1-7) to give a sense of the context for the Syriac passage to be considered below:

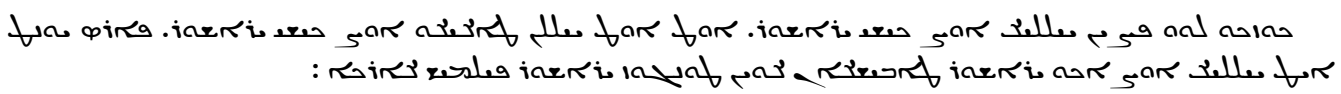

küskü luu bečin yıllıg üč kiši y(a)rašur : ud ud yllan takıgu üč kiši y(a)rašur . bars yunt it yillıg üc̆ägü y(a)rašur tavišgan koyn tonuz y(a)rašur bilmiš k(ä)rgäk : (Zieme 2015: 116)

The three people of the mouse, dragon and monkey years are suitable (for each other). The three people of the ox, snake and chicken years are suitable (for each other). All three of the tiger, horse and dog years are suitable (for each other). The rabbit, sheep and pig (years) are suitable (for each other). Knowing (this) is necessary.

The Syriac passage cited in U 328 is different in content from the Uyghur portion of the text discussed above, but related in genre. Indeed, as already noted, the fact that it is written in Syriac script clearly shows that it was used in the Christian community. At the same time - and in contrast to the theologically orthodox language of some Uyghur Christian texts, such as a creed found at Turfan (Zieme 1997/1998; Zieme 2015: 43-47) - U 328 contains material which can be considered peripheral to the official concerns of the Church of the East. Nonetheless, it conveys important information about the practice of Christians at Turfan (and probably throughout Central Asia) during the mediaeval era, particularly related to the desire for aid from the supernatural or spiritual world for the concerns of daily life.

12 An instance of dittography on the part of the scribe. 


\section{THE SYRIAC PASSAGE - TEXT AND TRANSLATION}

Following the aforementioned Uyghur text about the twelve-year animal cycle, the second word on line 7 of the verso gives the heading for a new section: + 'writing for penning a horse' (lit. 'horse penning writing'). A discussion of the three Turkic words in the heading is in order. The first word, $\downarrow \sim a$ t, is the standard word in nearly all Turkic languages for 'horse, specifically a horse that is meant to be ridden (Clauson 1972: 33). ${ }^{13}$ The third word, ‥ bitig, has a broad range of meaning, referring to anything that can be written down, including inscriptions, books, letters, and other documents (Clauson 1972: 303). In this case, it seems to be referring to what we might call an amulet or talisman (terms to be discussed below).

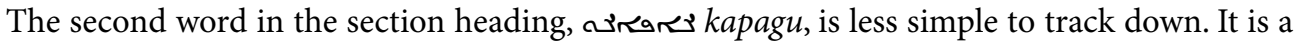
noun (not found elsewhere in Turkic literature), here translated as 'penning'; the ending - $g u$ is classified by Marcel Erdal (2004: 301) as a 'projection participle,' which is 'used for presenting projections of expectations, evaluations and intentions.' Commenting on related etymologies, Talat Tekin (1994: 255; see also Clauson 1972: 580) notes that Old Turkic 'kapıg or kapag 'gate, door'... are derivatives of *kap- 'to shut, close', a verb already obsolete in Old Turkic.' This is reflected in the Modern Turkish verb kap-, 'to shut, close... to shut up... to blockade, to block... to confine, to imprison' (Alkım et al. 1998: 596). ${ }^{14}$ Related words found in Turkic literature include 1) kap, 'leather bag, water skin, sack, vessel, container' (Clauson 1972: 578); 2) kapak, 'something which covers or closes' (Clauson 1972: 582-583); and the aforementioned 3) kapıg (also spelled kapag, kapug), 'door, gate' (Clauson 1972: 583). ${ }^{15}$

The Syriac passage (Fig. 3) begins at the very end of line 7 with the letters $\infty$ and $i$ and extends at least to line 10 , beyond which the ravages of time have reduced our text to a tattered lower edge; line breaks are indicated by $\mid{ }^{16}$

\footnotetext{
13 An alternate word for 'horse,' yunt ( $\downarrow$ $\sim$ in Syriac script), is used to designate the year of the horse in the horoscope section discussed above, as well as on Christian gravestones in Syriac script from Central Asia (e.g. see Dickens 2009b: 37, 38).

${ }^{14}$ Related Modern Turkish words include kapak, 'lid, cover'; kapal, 'shut, closed, covered'; kapı, 'door, gate.'

${ }^{15}$ One of the anonymous reviewers of this article raises the question of whether there may have been two verbs in Old Turkic, namely ${ }^{\star} k a p$-, 'to shut, close' and kapa- 'to fence in,' with our text reflecting the latter, rather than the former. If so, this may require a reinterpretation of the name of the Turkic qaghan mentioned in the Tonykuk inscription, E1: J ' I J IN, QPGN QGN (Tekin 1968: 252, 289; the text and translation can also be found at https:// bitig.kz/?lang=e\&mod=1\&tid=1\&oid=17\&m=1). Rather than Qapghan Qaghan (as Erdal 1991: 385 interprets it, translating the meaning of the name as 'snatcher... an appropriate name in a society in which martial qualities were highly prized'), his name may have been Qapaghan Qaghan, 'the one who fences in', referring to his ability to protect his subjects from attack by others.

${ }^{16} \mathrm{I}$ am exceedingly grateful to Thomas A. Carlson for his assistance in fine-tuning the reading of the extant Syriac text and the translation. His assistance with matters both palaeographical and grammatical was invaluable in avoiding various pitfalls in my interpretation. Any remaining errors are mine.
} 


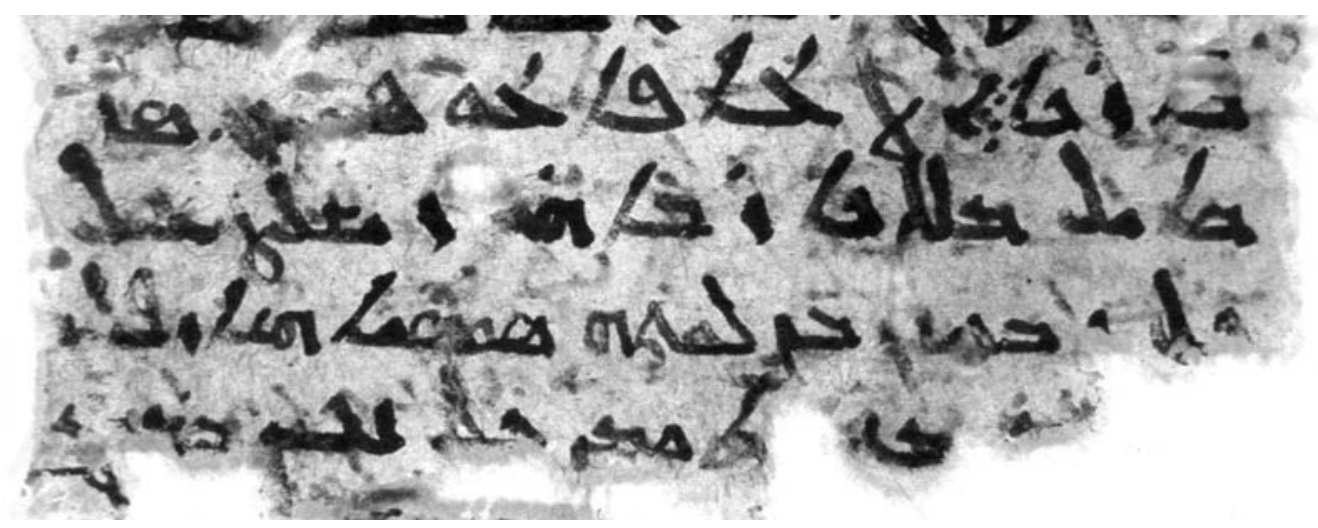

Fig. 3 U328 Syriac extract

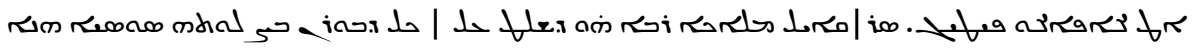

$$
\begin{aligned}
& { }^{20}[\text { [ ] }
\end{aligned}
$$

[Uyghur] Writing for penning a horse: [Syriac] Saraqael the archangel, he who has mastery ${ }^{21}$ over all, our guide in his prayer (for) this horse, which he has sav [ed from] de[ath] and from all harm, in (?) $[\ldots]^{23}$

It is unclear how much further the Syriac passage went in the now-missing section of the original manuscript. The visible text seems to be largely made up of clauses that depend on the initial reference to Saraqael. The missing text and speculative nature of the above reconstruction makes a full assessment of the original well-nigh impossible. Nonetheless, we can still say some things about this enigmatic Syriac passage.

The issue of the angel's name will be addressed below, mainly because it gives us clues to the ultimate origins of this Syriac passage found in U 328. Another matter related to the interpretation of the text is the Syriac word raon (susāya), which can mean 'horse' (as in the translation above) or 'tending, care of the sick' (Payne Smith 1903: 368; Brock and Kiraz 2015: 149; cf. Payne Smith 1879-1901: col. 2574). Given the section heading on line 7 ('writing for penning a horse') it

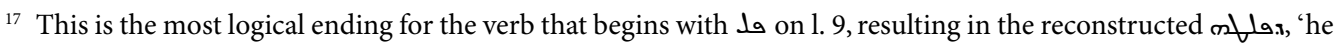
has saved/rescued him' (pa'el form of the verb).

${ }_{18}$ One can just see the top of $\rightarrow$ on this line.

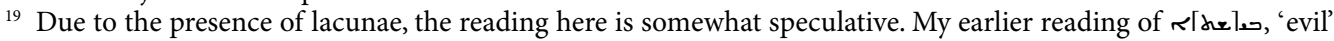
(reflected in Hunter and Dickens 2014: 490, on which see below) is untenable based on the visible remnants of Syriac characters.

${ }^{20}$ The remnants of this word could be read in a number of different ways; only the initial $\neg$ seems secure. The previous reading of [x $\mathrm{m}$ ] ${ }^{21}$ This might equally be rendered as 'he who rules,' he who prevails' or even 'he who gives power.'

${ }^{22}$ Or 'rescued, delivered.'

${ }^{23}$ This reading differs from that found in Hunter and Dickens 2014: 490: The great angel Saraqael, he who rules over every blessing. By his prayer this healing that [separates from evil] and from all harm. In the name [of...].
} 
seems obvious that the scribe who inserted this passage in U 328 understood susāya as referring to a horse (although we should note that the embedded prayer speaks of a horse being saved from death and harm, not being successfully captured and enclosed in a corral, so there is a clear disconnect between the Syriac text and the Uyghur heading). We do not know whether the scribe composed the Syriac passage himself or took it from somewhere else. If the latter, it is possible that the original form of the prayer may have used susāya in the sense of 'caring for the sick' (there are certainly far more Aramaic and Syriac amuletic texts that are concerned with healing and health than with horses).

The profession of the Christian scribe who wrote out U 328 is discussed below; it is highly likely that he (the scribe was almost certainly male) was reasonably well-versed in Syriac, although probably not a native speaker. The scribe presumably understood enough Syriac to know that susāyā means 'horse' but did he understand the other possible meaning of 'caring for the sick'? In other words, are we dealing with a text which was originally connected with health and healing, transformed into a talisman to contain a horse (an important concern for Central Asians, whether nomads or settled agriculturalists)? ${ }^{24}$

\section{THE WHY, WHO AND WHERE OF THE TEXT}

The questions that immediately come to mind about the embedded Syriac text have to do with its purpose and authorship. Regarding the first consideration, as noted above, we seem to be dealing with the remnants of a book of some sort which contains a description of the positive and negative effects of the days of the month, various pharmaceutical recipes designed to address common ailments such as baldness, advice on how to match people based on their birth year and finally our Syriac text, designed to enable someone to corral a horse. ${ }^{25}$

What are we to make of this interesting mixture of texts, all seemingly designed to answer questions along the lines of 'What do I do about this activity I plan to do on such and such a date? What do I do about the fact that I am losing hair? What do I do about finding a suitable partner for my son or daughter? What do I do about my need to capture a horse and enclose it in a corral?' Given the texts that it contains, U 328 seems to have been intended as a book of 'recipes' (whether amuletic or pharmaceutical) which could be copied and personalized for those requesting help in some area of their life (Hunter 1999: 161). Considering these matters related to the purpose of the text leads us to ask, 'Who would likely have written down these texts?' Obviously it was someone literate in at least the Syriac script and, to some degree, the Syriac language. Almost certainly we are dealing with a Christian cleric or monk. ${ }^{26}$

\footnotetext{
24 Admittedly, there are other Syriac words more commonly used to indicate the notion of healing, such as

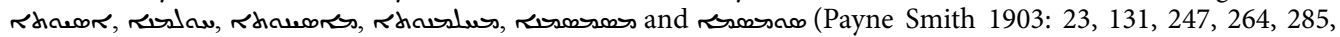
367; Brock and Kiraz 2015: 8, 51, 90, 99, 109, 148). Given the fragmentary nature of the extant text, it seems futile to speculate any further on the exact content and meaning of the original source.

${ }^{25}$ For a discussion of similar texts in Khotanese, see Maggi 2008, which refers to amulets and omen texts used in 'folk' Buddhism, including a text 'forecasting men's fate on the basis of the year of the duodecimal animal cycle in which they are born.'

${ }^{26}$ Bhayro 2015: 131 observes a parallel phenomenon in Judaism, especially in Late Antiquity: 'professional magicians should probably be identified with the scribal guild that was located at the centre, rather than on the periphery, of the Jewish communities of Talmudic Babylonia.'
} 
This leads in turn to consideration of where the text was written. According to the original signature number attached to U 328 - T III Kurutka 1853 - it was found at Kurutka, a village in the Turfan oasis where a number of other Christian texts were also found, specifically SyrHT 317323 (Hunter and Dickens 2014: 293-298; Raschmann 2009: 285-286), U $329+$ U 330 + U 333 + U 334 + U 336 (Zieme 2015: 71-84; Raschmann 2009: 219-221), U 332 (Zieme 2015: 139-141), U 5850 (Raschmann 2009: 115-116), U 7264 (Zieme 2015: 107-111) and ${ }^{\star} U 9237$ (Raschmann and Sertkaya 2016: 34-35). Most Christian texts from Turfan were found at Bulayïq (a village located approximately four $\mathrm{km}$ from Kurutka), probably the location of a Christian monastery (Sims-Williams 1989). Although U 328 may indeed have been written in Kurutka (in which case perhaps by a priest in the local church there), we cannot rule out the possibility that the ultimate origin of U 328 was the nearby Christian monastery at Bulayï. Unfortunately, the Turfan Expedition Archives in Berlin do not contain more detailed descriptions of the actual location where $U$ 328 was found in Kurutka. ${ }^{27}$ However, if the text did ultimately originate in Bulayï, then it must be understood within the broader context of the function of monasteries in the Church of the East (and indeed in other branches of the Christian Church as well).

Christian monasteries, certainly in the Christian East, have always been places where people (whether Christian or not) have gone to find physical healing, protection from harm and answers to prayer. ${ }^{28}$ In particular, cures and prayers have been distributed by various means over the centuries, often so that the supplicant could take away a physical token of the spiritual blessing in order to achieve the desired aim, whether to produce healing, attract good fortune or keep away bad luck and harm. Indeed, the idea that a physical token can be a vehicle of healing or the answer to prayer from a saint can be traced back to apostolic times, when we read that 'God did extraordinary miracles through Paul, so that when the handkerchiefs or aprons that had touched his skin were brought to the sick, their diseases left them, and the evil spirits came out of them' (Acts 19:11-12, NRSV).

This impartation of physical tokens in order to transfer spiritual blessing is clearly illustrated by the practice of East Syriac monks as described in the Book of Governors (Historia Monastica) by Thomas of Marga (ca. 840). In one story, the son of a Christian Arab who was deathly ill was cured after Mar Cyriacus, the head of the monastery of Beth 'Abhe, sent a washing from the cross of Rabban as 'a means of grace' to heal the son (Budge 1893: 422-425). ${ }^{29}$ Additionally, the prayers of a holy man were often accompanied by wen henāa, a mixture made from dust from a martyr's relics, oil and water. This substance was regularly given to those who came to monasteries asking for prayer. $^{30}$

Some of the most common physical tokens which might be dispensed by clergy were amulets or talismans. ${ }^{31}$ These objects, concealed in clothing or displayed in a dwelling, were inscribed with a text considered to contain spiritual power. This genre of religious texts has a long history in the Middle East, particularly amongst the speakers of Semitic languages; the broader category

\footnotetext{
27 I am indebted to Simone-Christiane Raschmann of the Göttingen Academy of Sciences for this information.

${ }_{28}$ The same could be said about holy places in other religious traditions, such as shrines and tombs of saints in Islam and monasteries in Buddhism.

29 Similarly, in certain iterations of folk Islam, Qur'anic texts are written in ink and then dissolved in water to be drunk as a way of 'taking in the Word of God' for healing purposes, on which see, for example, Nieber 2017.

${ }^{30}$ For examples of its use, see Budge 1893: 600, 602, 603, 606, 611, 618, 666, 669.

31 Some use the terms interchangeably. Others distinguish between an amulet and a talisman; 'the former are designed to repel what is baneful; the latter, to impel what is beneficial' (Gaster 2005: 298).
} 
of what are often referred to as magical and divination texts (on which, see below) can be found in popular Judaism from the Second Temple period on, with the ultimate roots going back to Babylonian religious practices (Gaster 2005: 299; Patai 2005; Inhorn 2005: 3837; Fahd 2005). Indeed, amulets and incantation bowls in Judeo-Aramaic, Mandaic and Syriac (as well as a good many in what is best described as 'pseudo-script') ${ }^{32}$ have been discovered throughout the Middle East and there is a growing literature on this genre (see the discussion below, as well as Hazard 1893; Gollancz 1912; Montgomery 1918; Budge 1930: 272-282; Harviainen 1978; Naveh and Shaked 1985; Gignoux 1987; Hunter 1987; Hunter 1990; van Rompay 1990; Hunter 1993; Naveh and Shaked 1993; Hunter 1999; Segal and Hunter 2000).

Given this background in Semitic culture, it is not surprising that such texts were used by Syriac Christians. Extant amulets from eighteenth and nineteenth century Kurdistan testify to the need for divine protection that East Syriac Christians felt in the midst of an unstable political situation, where they were often at the mercy of local Kurdish tribesmen. ${ }^{33}$ These amulets typically invoke a famous saint, angel or other entity (sometimes involving a mystical name) and contain the language of anathema, banning, binding and loosing, the thought being that recitation of the correct formula will oblige the entity invoked to carry out the request named in the prayer. ${ }^{34}$

As Erica Hunter (1987: 83) notes, these amulets were customarily written and dispensed 'either by priests or by men with priestly connections, ${ }^{35}$ especially in early modern times, when monasticism had disappeared in East Syriac Christianity; the practice seems to have continued into the early twentieth century (Hunter 1993: 248). Although Western scholarship has traditionally viewed these practices and the literature associated with them as 'superstitious' and therefore suspect, they can also be viewed as an integral part of the therapeutic and prophylactic ministry that the Church of the East offered to those who came to village churches and monasteries looking for help. Indeed, amulets can be considered para-liturgical items, since they reference spiritual beings and practices that are rooted in the liturgy of the Church of the East. ${ }^{36}$

The presence of such texts amongst the Christian manuscript fragments from Turfan - whether in Syriac, ${ }^{37}$ Sogdian (Sims-Williams 2020) or Uyghur fragments such as U 328 - testifies to their use in Central Asia hundreds of years prior to the examples from Kurdistan. ${ }^{38}$ Following the classification scheme for Syriac amulets suggested by Hunter, the passage in U 328 can be located under the bestowal genre of amulets, 'named after the benevolent, productive and positive tenor of the contents' (Hunter 1990: 366). ${ }^{39}$

It seems fitting to close this discussion of the likely clerical involvement in the authorship of $U$ 328 with the thoughts of Marco Moriggi (2016: 382) on:

\footnotetext{
${ }^{32}$ I am indebted to one of the anonymous reviewers of this article for this insight.

${ }^{33}$ Many such amulets are included in Gollancz 1912. See also Hunter 2009.

${ }^{34}$ On incantation texts in general, see Ludwig 2005.

35 On the use of these amulets amongst the 'Nestorian' Christians (as they are referred to in literature from the nineteenth and early twentieth centuries), see also Hunter 1993: 243-244; Hunter 1999: 161-162. A typical example of the attitude of English missionaries towards this practice can be found in Badger 1852: 238-240.

${ }^{36} \mathrm{I}$ am indebted to Erica Hunter for this terminology and approach to the genre of amulets.

37 One Christian amulet from Turfan, extant in two partial fragments (SyrHT 99 and SyrHT 330), is described in Hunter 2013. Two other fragmentary amulets, both dedicated to Mar Cyprian (SyrHT 102 and n 364-365) are discussed in Hunter 2018.

${ }^{38}$ As Hunter 2013: 35-37 points out, there is at least one other extant Syriac amulet from the ninth or tenth centuries, the same period as the Turfan Syriac documents, namely British Library Add. 14653.

39 The other three amulet genres outlined in this article are anathema, binding and expulsion.
} 
a clergy who were in the same way aware of articles of Christian faith but whose cultural background embraced issues coming from old pagan traditions, older or contemporary religious movements (e.g. Manichaeism), Jewish tradition, etc. The clergy may themselves have thus indulged in the magical practice as it was a crucial component of its cultural milieu as well as of the laity. While Church authorities tried to eradicate magic practice and condemned it in solemn homilies, the priests and deacons may have started a process of 'Christianization' of texts and users, in order not to let the laity continue to believe in magic outside Christianity.

\section{INITIAL REFLECTIONS ON THE ANGELIC NAME SARAQAEL}

The angelic name Saraqael in our text is of interest for several reasons, the most obvious of which

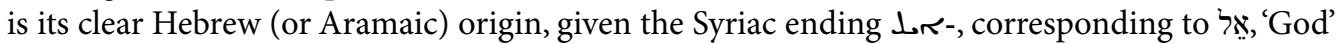
in the original language and usually transliterated into English as -ael or -iel. Indeed, the name strongly suggests that the Syriac passage embedded in U 328 originated in a Hebrew-Aramaic matrix - or at the very least, elements of the passage originated in that context. Also pertinent to our investigations below is the reference to Saraqael as rarchangel,' a reminder that the text invokes not just any angel, but one of the more exalted ones.

In light of the obvious Hebrew-Aramaic connections, a few observations based on Gideon Bohak's insightful Prolegomena to the Study of the Jewish Magical Tradition (2009) are perhaps in order here (acknowledging that the terms 'magic' and 'magical' are considered problematic by some in academic scholarship ${ }^{40}$ ). As in Judaism, so in the Syriac world there has been 'recourse to learned, professional magic... transmitted from one generation to the next and from one... community to the other through the medium of written texts' (Bohak 2009: 111). Also germane to our discussion here is Bohak's observation (2009: 115) that 'many elements from the Jewish magical tradition often crossed over into the non-magical spheres of Jewish culture, and many nonmagical elements crossed into the magical tradition' - we might say the same about Syriac culture, with amuletic texts using language commonly found in liturgical, prayer and hagiographical texts.

Even more pertinent to the subject of this article and as applicable to Syriac Christians as to Jews is the assertion that 'a magic ritual borrowed by Jews in one cultural context could very quickly be transmitted to the other end of the Jewish world and re-surface in a totally different cultural context, ready to be truncated and wedded to more local materials' (Bohak 2009: 118). Indeed, as will be discussed below, the trajectory of a 'formula which is attested already in the Dead Sea Scrolls... re-emerging in several unpublished Babylonian incantation bowls and... in a magical recipe from the Cairo Genizah' (Bohak 2009: 119) may well have its parallels in the Syriac text under consideration here.

Certainly, in both the Jewish and the Syriac Christian world, amulets and other magical texts were capable of moving across great distances, both chronologically and geographically, such that 'magicians of later periods had more access to ancient textual materials-such as the story of the

${ }^{40}$ As Middleton 2005: 5562 notes, what we refer to as 'magic' is concerned with 'acts by which [people] intend to bring about certain events or conditions, whether in nature or among people, that they hold to be the consequences of these acts.' I do not intend any connotations of superstition or primitivism by use of the term 'magic' in this paper. 
Fallen Angels which is known to us from the 'apocryphal' literature of the Second Temple period-than we would otherwise have imagined' (Bohak 2009: 119). In all this, as we examine texts concerned with divination and other areas of magic, we find that 'the People of the Book' and 'the people of the magical recipe books... often turn out to be the very same people... magic is endemic within all three monotheistic traditions, in spite of their insistence that it is not' (Bohak 2009: 122).

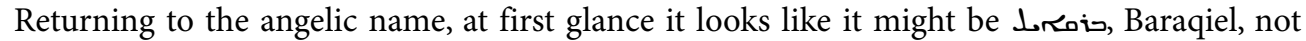

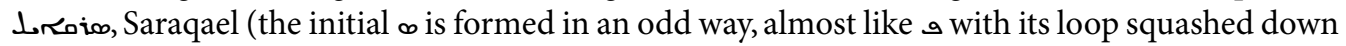
towards the baseline of the letter). Indeed, as explored below, Baraqiel occurs not infrequently on amulets and incantation bowls, as well as in other texts, but Saraqael occurs only once in extant examples of these texts. However, although the initial $\infty$ is curiously formed, comparison with the two occurrences of $\infty$ in the subsequent word reon confirms that the name should be read as Lroin, Saraqael. ${ }^{41}$

At the same time, however, one wonders if the original text might have contained Baraqiel or (less likely) Barakiel. As Edwin Yamauchi (1965: 519) points out, 'Some of the names of the angels in the magical texts are related to the function that they are to perform.' Thus, Barakiel and Baraqiel relate to the Semitic roots حi ( حin ( lighten. ${ }^{32}$ Both of these are much more positive in meaning than the Semitic root $\sqrt{S R Q}$ (סרק / مio), meaning in Aramaic 'to comb, card, hatchel', as well as 'to stain wood; to paint' (Jastrow 1903: 1029-1030), ${ }^{43}$ and in Syriac 'to comb... to torture with an iron comb... to make to be in vain, to bring to naught' (Payne Smith 1903: 392-393; Brock and Kiraz 2015: 157; cf. Sokoloff 2009: 1050). Could it be that an earlier exemplar of this Syriac text contained the name Baraqiel, "lightning of God,' later changed to Saraqael, 'comb of God' due to an orthographic error by a scribe who was not aware of the different Semitic roots? This is, of course, merely speculation, but at any rate, the name Saraqael has an odd meaning. ${ }^{4}$

\section{EXCURSUS ON THE BOOK OF I ENOCH}

Where do we find the name Saraqael, specifically as an angelic name? In fact, as far as I can tell, it only occurs in this form in two sources, 'a short Jewish magical text of a Late Antique Babylonian provenance' (Bohak 2013), to be discussed below, and the Ethiopic (hereafter referred to as Ge'ez) Book of I Enoch, a version that was likely produced 'during the earliest period of Ethiopic literature (c. A.D. 350-650)' (Isaac 1983: 8). We start here with a consideration of the evidence from I Enoch, considered canonical by the Ethiopian Orthodox Church and the Eritrean Orthodox Church, but not by any other branch of Christianity. At this point, a brief excursus on I Enoch may be helpful.

\footnotetext{
41 Indeed, the letter is also written similarly in several places in the Uyghur text on the upper fragment - only final $\varphi$ is formed in the traditional fashion with two adjacent loops.

42 For more on these angelic names, see Davidson 1971: 69-70 (s.v. Barakiel, Baraqel, Baraqijal, Barkiel).

43 Note also the derivative meaning of 'barrenness, desert.'

${ }^{44}$ I think we can discount an etymology of the angelic name from סרקי, 'Saracen, desert-dweller' (Jastrow 1903: 1030).
} 
Unravelling the historical context, textual history and thematic content of I Enoch is difficult and beyond the scope of this article. ${ }^{45}$ The book is part of what is commonly referred to as the Jewish Apocrypha or Pseudepigrapha (terminology which is not accepted by all scholars). ${ }^{46} \mathrm{Al}$ though it is not a canonical part of the Hebrew Bible, it was hugely significant in early Christianity and, as the discovery of Aramaic fragments of the book at Qumran demonstrate, also in Second Temple Judaism. I Enoch details revelations supposedly given to Enoch, the righteous antediluvian descendent of Adam who, in the words of Genesis 5:24, 'walked with God; then he was no more, because God took him' (NRSV) ${ }^{47}$ In the book of I Enoch, its namesake sees visions and experiences heavenly journeys in which he gains spiritual insight and predicts human history; angels play an important role in many of these events and in the book as a whole. Indeed, the question of why and how certain angels fell from their original state of grace is a major theme in the work.

It is perhaps no surprise that we find the angelic name we are seeking in I Enoch, written as it was during the Second Temple period. As Charles A. Gieschen observes,

Jewish literature of the centuries immediately before the Common Era testifies to a general cosmological development that emphasized God is enthroned in heaven while carrying out his work in the world by means of angelic leaders who have myriads of other angels at their command... The giving of a personal name to an angel is significant. It further distinguishes or separates the angel as an individual figure distinct from God... Indeed, as amazing numbers of angels in service to God were depicted (e.g., Dan 7.10 or 1 En. 71.8), a hierarchy of angelic leaders also was depicted and labeled as 'Angels of the Presence' or 'Archangels' (Gieschen 1998: 124). ${ }^{48}$

The Book of I Enoch is generally divided into five sections: 'the Book of Watchers' (ch. 1-36), 'the Similitudes' or 'the Book of Parables' (ch. 37-71), 'the Astronomical Book' (ch. 72-82), 'the Book of Dreams' (ch. 83-90), and 'the Epistle of Enoch' (ch. 91-108). ${ }^{49}$ In fact, we can think of I Enoch as 'not just one work, but... five separate compositions' (Collins 1989: 33), which constitute 'a developed 'scientific' lore about astronomy, calendar, cosmology and angelology' (Stone 1991: 192). One of the earliest of these constituent parts of I Enoch - and, along with the Astronomical Book, 'the oldest, extra-biblical Jewish religious literature' (Stone 1991: 189) - is the Book of Watchers, from which most of the passages discussed below are taken (not surprising, given the central

\footnotetext{
${ }^{45}$ On the possible historical and social context, see Collins 1989: 56-63; Stone 1991: 184-197. See also the discussion in Reed 2005a.

${ }^{46}$ For an insightful discussion of the status of I Enoch and the Book of Jubilees at Qumran and the implications this has for the notion of the Hebrew biblical canon, see Reed 2005b. For a discussion of the concept of 'Old Testament Pseudepigrapha, see Reed 2009.

47 On the figure of Enoch, see Collins 1989: 34-36.

48 For a list of angelic (and demonic) names gathered from 'extra-canonical apocalyptic literature' prior to $100 \mathrm{CE}$, see Barton 1912. References to I Enoch (which make up the majority) in that article are taken from Dillmann 1853 or Charles 1893. Curiously, Saraqael does not appear in the list, only 'Saraquyal, according to Dillmann's text, one of the evil archangels (Eth. En. 6 7). Charles reads better, Baraqiyal' (Barton 1912: 165); see further on this in the discussion of I Enoch 6:7 below.

49 Although this is the traditional way to view the sections of I Enoch, some would divide the Book of Watchers into smaller constituent parts (see, for example, Black 1985: 12-23).
} 
role that angels play in that book).$^{50}$ Regarding its origins, Ida Fröhlich (2016: 102) notes that 'the primary tradition that survives in the Aramaic manuscripts of the Astronomical Book, the Book of Watchers, and the Book of Giants [discussed below] - was shaped in the Eastern (Babylonian/ Syrian) Jewish diaspora'.

The influence of the book on Christianity can be seen as early as the following quotation from I Enoch 1:9, found in the New Testament Epistle of Jude, verses 14-15: 'See, the Lord is coming with ten thousands of his holy ones, to execute judgment on all, and to convict everyone of all the deeds of ungodliness that they have committed in such an ungodly way, and of all the harsh things that ungodly sinners have spoken against him' (NRSV). ${ }^{51}$ The book also influenced a number of early Christian writers, including Justin Martyr (d. ca. 167), Tatian (d. ca. 172), Athenagoras (fl. ca. 180), Irenaeus (d. ca. 200), Clement of Alexandria (d. ca. 215), Tertullian (d. ca. 220), Hippolytus (d. ca. 236), Origen (d. ca. 254) and Cyprian (d. 258). ${ }^{2}$

Until the late eighteenth century, I Enoch was only known from Greek excerpts preserved by the Byzantine historian George Synkellos (d. after 810), who includes the whole of 6:1-9:4 (excerpts from which are discussed below) under the heading 'From the First Book of Enoch concerning the Watchers' (Adler and Tuffin 2002: 16-18), probably taken from Julius Africanus' non-extant Chronicle (Adler 1989: 10). Manuscripts of the Ge'ez version of I Enoch initially reached Europe in 1773, with the first edition of the full text - still to this day, preserved only in $\mathrm{Ge}^{\mathrm{c}} \mathrm{ez}$ - published in 1838, followed by a critical edition of the text in 1851. A more complete Greek text of I Enoch (containing chapters 1-32) was discovered at Akhmin, Egypt in 1886/87 (now designated as Cairo Papyrus 10759 or Codex Panopolitanus) and published in 1892 (two additional manuscripts containing extracts from the Greek text of Enoch were published in 1844 and 1937). ${ }^{53}$ This was followed soon after by multiple translations from the Ge'ez text, as well as two new editions of the same text, by Johannes Flemming in 1902 and Robert Henry Charles in 1906 , both based on many more manuscripts than previous editions had used. ${ }^{54}$

A major step forward in research on I Enoch was taken when Aramaic fragments of eleven manuscripts of the book were found at Qumran in 1954, subsequently published by Józef Tadeusz Milik in 1976. The Qumran fragments, generally dated between the first and third centuries $\mathrm{BCE},{ }^{55}$ rendered 'very probable the view that Aramaic was the original language of the greater part of the work' (Knibb 1978b: 7). Unfortunately, the Aramaic material is very fragmentary and amounts to 'just under one-fifth' of the Ge'ez text, but 'it would appear that the Greek and Ethiopic texts provide a not too unreliable guide to the Book of Enoch as it was known at Qumrân' (Knibb 1978b: 12, 13). ${ }^{56}$

Regarding the relationship between these three versions, Michael Knibb (1978b: 22) suggests 'that the Ethiopic translators made use in their work of a Greek text of Enoch is certain; that they

\footnotetext{
${ }^{50}$ For a helpful introduction to the Book of Watchers, see Coblentz Bautch 2019; for an extended discussion, see Collins 1989: 36-46.

51 Additionally, 'three New Testament writings make explicit use of the angel story [from I Enoch]': I Pet. 3:19-20, Jude 6 and II Pet. 2:4 (VanderKam 1996: 62-63).

${ }^{52}$ Helpful expositions of the use of I Enoch by those listed and others can be found in VanderKam 1996.

53 On the manuscript evidence for the Greek text of I Enoch, see Milik 1976: 70-78; Knibb 1978b: 15-20.

54 This material is abbreviated from Knibb 1978b: 1-6.

55 On dating the Aramaic fragments, see Milik 1976: 5, 7, 22, 25, 41, 48, 58, 140, 141, 164, 178, 183, 225, 226, 246, $256,273,274$.

56 This information on the Qumran fragments is distilled from Knibb 1978b: 6-15.
} 
also made use of an Aramaic text is extremely probable. ${ }^{57}$ Indeed, when we consider that Ge'ez and Aramaic are both Semitic languages, it seems highly likely that, if they had access to it, the translators would indeed have used the Aramaic text. A major edition and English translation of the Ge'ez text of I Enoch was produced by Knibb in 1978, based on over 30 manuscripts. Another English translation by Matthew Black appeared in 1985, based primarily on the aforementioned edition (1906) and translation (1912) of Charles, with reference to the Aramaic and Greek fragments. In contrast to Knibb, Black (1985: 4) states, 'For all parts of the book there is general agreement that the Ethiopic is a tertiary version, a translation of a Greek Vorlage, itself rendering an Aramaic and/or Hebrew Grundschrift.'

But what of Syriac? Did it play a role in the evolution of the text of I Enoch? Interestingly, the Chronicle of Michael the Syrian (or Michael the Great, as he is called in the Syriac Orthodox tradition) quotes from I Enoch 6:1-7 (a section of interest to us, to be discussed below). ${ }^{58}$ Since Michael did not use any Greek sources, Sebastian Brock has argued that for this - 'the only genuine fragment of 1 Enoch to be preserved in Syriac' - Michael's 'immediate source was a Syriac, and not a Greek, one' although 'the underlying source-via Annianos [a fifth-century Alexandrian author]-was... the Chronography of the Alexandrian Panodoros (fl. c. 400)' (Brock 1968: 626, 627-628)..$^{59}$

Building on Brock's earlier observations regarding the identity of the Syriac intermediary source, William Adler (1994: 146) notes, 'in their chronicles, either John [of Litarba (d. 737/8)] or Jacob [of Edessa (d. 708)] himself translated a Greek excerpt from the Enochic Book of Watchers (I Enoch 6-36) into Syriac, thereby making Enochic literature available to a later generation of Syriac chronographers. ${ }^{60}$ However, lacking this intermediary source (whether translated by John, Jacob or another Syriac author), not to mention the original Greek works of Annianos and Panodoros, this avenue seems closed in the quest to determine the transmission history of the Syriac passage in U 328.

There are also allusions to or citations from I Enoch in other Syriac sources. An early and fairly clear allusion to Enoch - and one that is likely to indicate access to a Syriac version of the sto$\mathrm{ry}^{61}$ - is found in the Syriac Book of the Laws of Countries, by Bardaișan (d. 222), which speaks of 'the angels... [who] had intercourse with the daughters of men.' As James VanderKam (1996: 67) notes, 'while it echoes Genesis 6... [it] is probably based on the Enochic elaboration of Gen 6:1-4.' Another early Syriac source of interest is the Acts of Thomas (early third cent.), which includes 'an encounter with a serpent' who boasts of being 'he who hurled the angels down from above, and bound them in lusts for women, that earthborn children might come from them and I fulfil my will in them,' an account that 'mirrors the Enochic story' (VanderKam 1996: 72-73).

The Book of Steps (mid-fourth cent. to ca. 430) refers to how 'unclean spirits teach people [how] to hold them [swords] in their hands and kill one another secretly with a hidden sword just as with a visible sword' (Kitchen and Parmentier 2004: 71), a (rather vague) reference to I Enoch

\footnotetext{
57 See also the more extended discussion in Knibb 1978b: 37-46.

58 The French translation of the relevant sections can be found in Chabot 1899-1900: 3-5, 7-8.

59 This section of Michael's Chronicle dealing with the Watchers also exists in a Garshuni (Arabic in Syriac script) version of the Chronicle, discussed in Bhayro 2001.

60 See Brock 1968: 629 for the original suggestion regarding Jacob and John.

${ }^{61}$ Having said that, we should note that Bardaișan met Julius Africanus in Edessa in 195 (Brock 2011). Given what was mentioned earlier about Africanus being the likely source for quotations from I Enoch in George Synkellos, we might wonder if Bardaișan and Africanus discussed this story.
} 
8:1 (although there is no way to verify how the anonymous author of the Book of Steps accessed this Enochic material). Again, none of these Syriac references are helpful in tracing how the angelic name ended up in our text.

Material in a Syriac cosmological tract attributed to Dionysius of Athens which 'bears a close relationship to the 'book of the courses of the heavenly luminaries', that is, section iii (cap. lxxii-lxxxii) of the Book of Enoch' (Furlani 1917, 271) is also of no direct bearing on our search for the sources of the angelic name. Since we know next to nothing about the author of this pseudonymous work and his sources, we can only speculate about where and how he accessed the Enochic material used in his work; it may have been Syriac, but it may also have been Greek.

Finally, we may note that there are several references to the story of the angelic Watchers in the Book of Jubilees. ${ }^{62}$ Like I Enoch, this too is an example of Jewish Pseudepigrapha preserved in part by fragments found at Qumran (albeit in Hebrew rather than Aramaic), but in full only in Ge'ez. As with Enoch, Jubilees is also included in the biblical canon of the Ethiopian Orthodox Church and the Eritrean Orthodox Church. In contrast to Enoch, 'the existence of Syriac fragments of the Book of Jubilees [notably in the Anonymous Chronicle to 1234] makes it possible that it once existed in Syriac in its entirety, though this is uncertain' (Pedersen 2017: 191-192). ${ }^{63}$ Unfortunately, Jubilees does not provide angelic names in any of the Watcher references (Jubilees 4:15; 4:22; 5:1; $5: 6-10 ; 8: 3 ; 10: 1-7=$ VanderKam 1989: 25, 27-28, 31-32, 33, 50, 58-59). ${ }^{64}$

\section{THE ANGELIC NAME SARAQAEL IN I ENOCH}

In I Enoch 20:1-7, we read the following:

20.1. And these are the names of the holy angels who keep watch. 20.2. Uriel, one of the holy angels, namely (the angel) of thunder and of tremors. 20.3. Raphael, one of the holy angels, (the angel) of the spirits of men. 20.4. Raguel, one of the holy angels, who takes vengeance on the world and on the lights. 20.5. Michael, one of the holy angels, namely the one put in charge of the best part of mankind, in charge of the nation. 20.6. Saraqael [n6.\$\$A, Säraqa' eal in the Ge'ez script] (Knibb 1978a: 73; cf. Charles 1906: 52), ${ }^{65}$ one of the holy angels, who (is) in charge of the spirits of $m e n^{66}$ who cause the spirits to sin. 20.7. Gabriel, one of the holy angels, who (is) in charge of the serpents and the Garden and the Cherubim (Knibb 1978b: 106-107; cf. Charles 1912: 43-44; Black 1985: 36-37, 162-163; Isaac 1983: 23-24).

Chapter 20 in the Ge'ez version has only seven verses, but, as Knibb notes, the Greek Akhmin manuscript (Codex Panopolitanus) includes an eighth verse, which 'probably correctly, adds a

\footnotetext{
${ }^{62}$ For a helpful introduction, see VanderKam 2001: 11-21.

63 See also Adler 1994: 166 for a discussion of the quotations from Jubilees in the Anonymous Chronicle to 1234.

${ }^{64}$ On the story of the Watchers in Jubilees chapter 5, see Segal 2007: 103-143; van Ruiten 2000: 181-197.

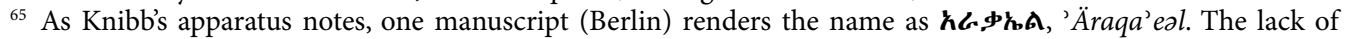
phonological relationship between the initial characters of $\boldsymbol{n}(s \ddot{a}$, in Säraqa'eal) and $\boldsymbol{h}$ (' $\ddot{a}$, in 'Äraqa'eal) shows that the variant resulted from scribal confusion over the initial letters.

${ }^{66}$ Italicization indicates places where the translator has diverged from the base text, Rylands Ethiopic MS. 23, because 'its evidence does not make sense and... better Ethiopic evidence is available' (Knibb 1978b: 47).
} 
seventh angel to the list' (Knibb 1978b: 107), reading 'Remiel, one of the holy angels, whom God set over those who rise' (Charles 1912: 44; Black 1985: 37, 163). ${ }^{67}$

Saraqael, then, is one of the Watchers, angelic beings that are mentioned - although they are not named, nor is their function clarified - in the book of Daniel. ${ }^{68}$ Almost certainly standing behind the notion of 'the holy angels who keep watch' found in the $\mathrm{Ge}^{\text {' }} \mathrm{ez}$ text is the Aramaic word עיר, 'guardian, angel.' As R.M.M. Tuschling (2007: 89) notes:

Although עיר is not attested in Biblical Hebrew... [it is] attested in the Aramaic fragments of 1 Enoch, 4Q202 iv 6 (4QEn ${ }^{\mathrm{b}}$ ar): [בנ]י עיריא]. This justifies us in assuming that עיר underlies the Ethiopic text of 1 Enoch whenever Watchers are mentioned... Most commonly the title refers to fallen angels... but they can be an especially exalted class of angels, e.g. 1 Enoch 20.

The text in I Enoch 20 is somewhat ambiguous, but (unlike other angelic lists discussed below) we are not dealing here with the 'fallen angels' that much of the Book of Watchers is concerned with. Rather, these are 'exemplars of angelic faithfulness. To the fallen angels and the seven wayward stars [discussed in chapters 6-16 and 18-19] are contrasted seven angels who watch over the inhabited world' (Reed 2016: 81).

As Gieschen (1998: 124-125) notes, typically in Jewish and early Christian works, the hierarchy of angelic leaders... usually consisted of four to seven angels, with one of them often identified as the highest of these leaders. Michael, Gabriel, and Raphael are primarily associated with this group. Uriel (also known as Suru'el), Phanuel and others are included with less consistency'. To this can be added the following footnote from Gieschen (1998: 125, n. 4): 'Other names of angels who may have been considered archangels by some groups include: Sariel or Surafel (1 En. 9.1); Asuryal (1 En. 10.1); Raguel, Saraqa'el (1 En. 20.1-7); Eremiel (4 Ezra 4.36); Dokiel (T. Ab. 13.10 [Long Rec.]); Gabuthelon, Aker, Arphugitonos, Beburos, Zebuleon (Gk. Apoc. Ezra 6.2).'

Alongside the more familiar Michael, Gabriel, Uriel and Raphael then, Saraqael functions amongst these 'holy angels' as the one who is appointed to oversee 'the spirits of men who cause the spirits to sin, an enigmatic phrase indeed! As we will see below, the term 'Watcher' is also used to refer to the angelic 'sons of heaven... who glimpsed the daughters of men, desired them, and decided to descend to them' (Fröhlich 2016: 99). Notably, this list in I Enoch 20 is 'the first list of the names and functions of the seven' (Dix 1927: 236.). ${ }^{69}$

\footnotetext{
${ }^{67}$ Note the very similar list of seven angels that is included in a Celtic 'Prayer to the Archangels for each day of the week', published in O’Nowlan 1905: Gabriel, Michael, Raphael, Uriel, Sariel, Rumiel, Panchel. Here Sariel is associated with healing and deliverance from evil: 'Sariel on Thursday I speak of, against the swift waves of the sea, against every evil that comes to a man, against every disease that seizes him.'

68 'I continued looking, in the visions of my head as I lay in bed, and there was a holy watcher, coming down from heaven' (Dan. 4:13). 'The sentence is rendered by decree of the watchers, the decision is given by order of the holy ones' (Dan. 4:17). 'And whereas the king saw a holy watcher coming down from heaven and saying...' (Dan. 4:23). All quotations from NRSV. As Boyarin 2007 notes, 'The exact interpretation of the name of this being [i.e. the watcher in the book of Daniel] is somewhat problematic... the Septuagint has simply angel. That the term means angel can be shown from the Genesis Apocryphon of the Dead Sea Scrolls... Also in the Zadokite Documents, the "Watchers" are associated with the legend of angelic intercourse with women... In Daniel itself, they seem to be some sort of heavenly council'.

69 The article includes a helpful discussion of the likely Babylonian origins of the sevenfold archangelic cohort. See also Arnold 2013: 12-13.
} 
Before moving on, we might take note of the following observation by John Arnold, which suggests that perhaps the angelic name Saraqael (along with Raguel) was more common in early Christianity but was censored later on. Referring to the time of Gregory of Tours (d. 594), Arnold (2013: 105) notes:

Calling angels by name needed to be avoided, or at least carefully supervised... That power had to be handled with great care in light of ecclesiastical instruction... Gregory may very well have respected another important canonical pronouncement regarding angels, this being the Gelasian Decree [early sixth cent.]... The Gelasian Decree both established the scriptural canon and excluded apocryphal books written by 'heretics and schismatics.' Forbidden apocryphal works included 'all amulets written all over with names not of angels, but rather of demons, so that they pretend' to be angels. Calling upon only the scriptural angels again avoided the invocation of Saraqiel, Raguel, and all other spiritual names that might very well disguise demons. ${ }^{70}$

This is obviously referring to Western Christianity, but we can imagine similar things taking place in Eastern Christianity, resulting in such names being excised from official ecclesiastical documents, to remain only in the literature of magic. This may explain in part the apparent lack of references to Saraqael in texts used by Christians, apart from I Enoch (the magical text discussed below appears to have been only used in Jewish contexts).

Although Chapter 20 is not the only place in I Enoch where the Watchers are mentioned, it is the only place in the work where Saraqael is unequivocally included as one of them, reflecting (at least in part) the multiple corrupted forms of these angelic names in the extant manuscripts. ${ }^{71}$ Indeed, a common scholarly view is that 'I Enoch 6-11 appears to integrate multiple versions of the angelic descent myth' (Reed 2004: 51; see also Reed 2005a: 340-341). In his revised transla-

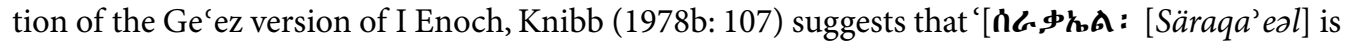

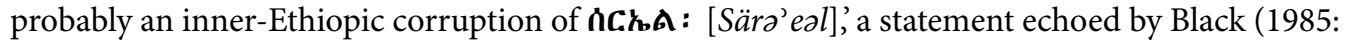
163), whose comment that 'Saraqael, otherwise unknown, seems an inner-Eth. corruption' must be revised in light of our Turfan fragment.

When the Watchers are initially introduced in I Enoch 6:1-8 (a passage that appears at first sight to be based on Genesis 6:1-42), we encounter a different list of angels. In contrast to the list in Chapter 20, where there is no hint of negative associations, the angels in Chapter 6 are presented as fallen, not pristine.

\footnotetext{
70 As Arnold (2013: 139) notes later on, 'Removing him from the company of Saraqael, Raguel, or Sosthiel eliminated the possibility of summoning evil.'

71 See, for example, the list of angelic names in I Enoch 6 in four important early manuscripts (two Greek and two Ge' ez) in the table in Charles 1912: 17 and an updated list including the Aramaic forms in Knibb 1978 b: 71.

${ }^{72}$ 'When people began to multiply on the face of the ground, and daughters were born to them, the sons of God saw that they were fair; and they took wives for themselves of all that they chose... The Nephilim were on the earth in those days - and also afterward-when the sons of God went in to the daughters of humans, who bore children to them.' (NRSV) In contrast to this traditional view of Enoch being dependent here on Genesis, it has also been argued that the reverse is more likely, specifically that this passage from Genesis 'represents a reflexion of the tradition that is evident in the Enochic story of the watchers' (Fröhlich 2016: 112). On this latter view, see Milik 1976: 30-32; Black 1985: 124-125.
} 
6.1 And it came to pass, when the sons of men had increased, that in those days there were born to them fair and beautiful daughters. 6.2 And the angels, the sons of heaven, saw them and desired them. And they said to one another: 'Come, let us choose for ourselves wives from the children of men, and let us beget for ourselves children.' 6.3 And Semyaza, who was their leader, said to them: 'I fear that you may not wish this deed to be done, and (that) I alone will pay for this great sin.' 6.4 And they all answered him and said: 'Let us all swear an oath, and bind one another with curses not to alter this plan, but to carry out this plan effectively.' 6.5 Then they all swore together and all bound one another with curses to do it. 6.6 And they were in all two hundred, and they came down on Ardis which is the summit of Mount Hermon. And they called the mountain Hermon, because on it they swore and bound one another with curses. 6.7 And these are the names of their leaders: Semyaza, who was their leader, Urakiba, Ramiel, Kokabiel, Tamiel, Ramiel, Daniel, Ezeqiel, Baraqiel, Asael, Armaros, Batriel, Ananel, Zaqiel, Samsiel, Sartael..., Turiel, Yomiel, Araziel. 6.8 These are the leaders of the two hundred angels, and of all the others with them (Knibb 1978b: 67-74; cf. Charles 1912: 13-16; Black 1985: 27-28, 116-124; Isaac 1983: 15-16).

Although the ninth name in the list (6:7) in Knibb's (1978a: 16; cf. Charles 1906: 14) Ge'ez text

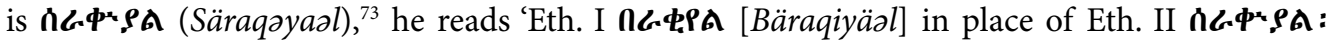
[Säraqayaal] ${ }^{74}$, since the Aramaic Qumran fragments have ברקאל (Baraq'el) here (Milik 1976: 150, 151, 188, 189; Knibb 1978b: 72-73; cf. Charles 1912: 16.), 'a name widely known in Semitic', which is attested in Phoenician, Amorite and Ugaritic texts, as well as possibly in a ninth century BCE Aramaic inscription (reconstructed as ברקאל) erected by the Aramean ruler Hazael at Tel Dan in northern Israel (Schniedewind and Zuckerman 2001: 90, citing Benz 1972: 292-293; Huffmon 1965: 178; Gröndahl 1967: 120-121). Echoing the Ge'ez text (Eth. II), the Ethiopic andamta (commentary) on Ethiopic Enoch 2 (1 Enoch 6-9) gives the name of the ninth angel as Suruqayal (Ge'ez $\mathbf{n} \cdot \boldsymbol{r}, \boldsymbol{\Phi}, \boldsymbol{P A}$, Suruqayaal), a variant of Saraqael (Lee 2014: 186).

In light of the above, our search for the origins of the angelic name in $U 328$ will take into account the possibility that there is some form of interaction going on between the two names Saraqael and Baraqiel. The latter, in the Ge'ez form n<.中9A, Bäräqä'aal (Knibb 1978a: 21; cf. Charles 1906: 18), appears again in I Enoch 8:3, in another list of fallen angels, along with the secret knowledge that they passed on to humans. Baraqiel is specifically described as the one who taught astrologers, although it is interesting that this also seems to have been the specialty of the angel Tamiel (Knibb 1978b: 82; cf. Charles 1912: 19.). ${ }^{76}$

8.2 And there was great impiety and much fornication [among humans], and they went astray, and all their ways became corrupt. 8.3 Amezarak taught all those who cast spells and

\footnotetext{
${ }^{73}$ Lacking knowledge of the Aramaic version of I Enoch, Dillmann 1853: 3 opts for Sarâqujâl, a choice interpreted by Schwab 1897: 260 [372] as שרקיאל, although this is unattested in any actual text (as opposed to סרקיאל, which occurs in the Pishra de-Rabbi Hanina ben Dosa, discussed below).

74 On the difference between the two manuscript groups Eth. I and Eth. II, see Knibb 1978b: 22-36.

${ }^{75}$ Indeed, it is possible that an orthographic error was introduced in the Gecez text here, given the similarity between the Ethiopic letters $\mathbf{n}(b a)$ and $\boldsymbol{n}(s a)$.

${ }_{76}$ Although the complete line is not extant in the Aramaic fragments, Milik 1976: 157, 158, 170, 171 suggests that it should read 'Baraq'el taught the signs of thunders', rendered in Black 1985: 29, 121, 128 as 'auguries [or signs] of the lightning,' reflecting the meaning of the angel's name, 'lightning of God.'
} 
cut roots, Armaros the release of spells, and Baraqiel astrologers, and Kokabel portents, and Tamiel taught astrology, and Asradel taught the path of the moon. 8.4 And at the destruction of men they cried out, and their voice reached heaven (Knibb 1978b: 81-84; cf. Charles 1912: 19-20; Black 1985: 29, 127-129; Isaac 1983: 16).

The final place in I Enoch where Baraqiel - in this case, Ge'ez nढ.\$PA, Bäraqayaəl (Knibb 1978a: 199; cf. Charles 1906: 122) - appears is 69:2, a list that was either 'copied from the Ethiopic version of $6.7 \ldots$ at a very late stage in the transmission of the text of Enoch' (Knibb 1978b: 160; cf. Charles 1912: 137) or that comes 'from a different Greek version of the Aramaic names' (Black 1985: 123). Indeed, 69:2 has similarities with the list of the rebellious angels found in 6:7, but there are also significant differences between the names included in the two lists.

69.2 And behold the names of those angels. And these are their names: the first of them (is) Semyaza, and the second Artaqifa, and the third Armen, and the fourth Kokabiel, and the fifth Turiel, and the sixth Ramiel, and the seventh Daniel, and the eighth Nuqael, and the ninth Baraqiel, and the tenth Azazel, the eleventh Armaros, the twelfth Batriel, the thirteenth Basasael, the fourteenth Ananel, the fifteenth Turiel, the sixteenth Samsiel, the seventeenth Yetarel, the eighteenth Tumiel, the nineteenth Turiel, the twentieth Rumiel, the twenty-first Azâzêl. 69.3. And these are the chiefs of their angels and the names of their leaders of hundreds, and their leaders of fifties and their leaders of tens (Knibb 1978b: 159-160; cf. Charles 1912: 136-137; Black 1985: 64-65, 245; Isaac 1983: 47).

Although the Ge'ez text of I Enoch 6:7 suggests that there may indeed be some sort of interaction between Saraqael and Baraqiel, it is also apparent by comparing 20:6 with 6:7, 8:3 and 69:2 that Saraqael is an archangel who is completely separate from evil, whereas Baraqiel is an angel who has succumbed to temptation.

What of the Greek and Aramaic fragments? What light do they shed on the matter? For the crucial verse of 20:6, we are reliant on the Greek, since the Qumran fragments do not include this passage. In contrast to Saraqael in the Ge'ez text, the Greek of 20:6 has $\Sigma \alpha$ on' $\lambda$ (Sariel) (Charles 1906: 53). A variant of this, $\Sigma \varepsilon \rho ı \eta(\lambda)$ (Seriel), occurs in 8:3 (Charles 1906: 19), where the Aramaic has שהריאל (Sahri' el, on whom see below), here designated as the one who 'taught the signs of the moon' (Milik 1976: 157, 158, 170, 171) and the Ge'ez text has hin.S.'̌.A ('Äsaradə'ial), glossed above as Asradel (Knibb 1978a: 22; cf. Charles 1906: 18). As with Baraqiel, the apparent interaction between Saraqael and Sariel suggests that our search should consider occurrences of this name also.

More will be said of Sariel below, but here we may note that a variation of his name features in the Synaxarium (calendrical martyrology) of the Coptic Orthodox Church. In the entry for the twenty-seventh day of the month of Toba, we read وفى هذا اليوم ايضا تذكار الملاك سوريال احس الاربعة الروساء المسمى السافورى Also on this day is the memorial of the angel Suriyal, one of the four principals [principal angels] called the Trumpeter' (Basset 1915: 710). ${ }^{77}$ This is a reference

77 My thanks to Amina Elbendary and Wadie Aboul Lif for identification of the final Arabic term السافورى, 'trumpeter,' with reference to Graf 1954: 56. 
to the four archangels that feature in texts from Jewish, Christian and Manichaean sources, as discussed below. ${ }^{78}$

Sariel also appears in another pseudepigraphical text, extant only in Old Church Slavonic: the Ladder of Jacob. This work, probably composed in either Hebrew or Greek, is based on the biblical story in which Jacob dreams of 'a ladder set up on the earth, the top of it reaching to heaven; and the angels of God were ascending and descending on it' (Gen. 28:12, NRSV). The apocryphal text includes an extensive section (Ch.3-5) in which the dream is explained to Jacob, introduced as follows (Ladder of Jacob 3:1-3):

And while I was still saying this prayer, behold, a voice came before my face saying, 'Sariel, leader of the beguiled, you who are in charge of dreams, go and make Jacob understand the meaning of the dream he has had and explain to him everything he saw; but first bless him.' And Sariel the archangel came to me and I saw (him), and his appearance was very beautiful and awesome (Lunt 1985: 408; see also Kugel 2006: 25-26).

Interestingly, in an earlier translation of this text, we find the following variation on the angel's name: 'Sarekl, prince of them that rejoice (or of the servants), thou that art over visions...' (James 1920: 98). Unfortunately, without having access to the original manuscripts used in these two translations, it is impossible to check the spelling of the angel's name, but the similarity to Saraqael is intriguing.

There are also other forms which bear a similarity to Greek $\sum \alpha \rho$ ı́ $\lambda$ (Sariel) or $\sum \varepsilon \rho ı \dot{~}(\lambda)$ (Seriel), chiefly the aforementioned שהריאל (Sahri' el), 'moon of God,' which (in addition to 8:3) also

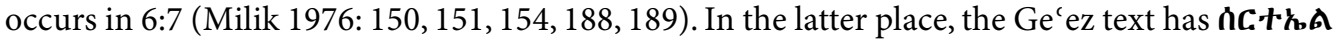
(Säratä'eal) (Knibb 1978a: 16; cf. Charles 1906: 14) and the Greek has Lapıvá (Sarinas) in Synkellos versus $\Sigma \alpha \theta i \eta$ (Sathiel) in the Cairo Papyrus; these can be derived respectively from an original $\Sigma \alpha \rho ı \eta j \lambda$ or $\Sigma \alpha \varepsilon \rho ı \dot{\lambda}$ (both essentially pronounced Sariel) (Milik 1976: 154; Charles 1906: 15).

Additionally, there is one place in the Aramaic Qumran fragments - 9:1 in the fragment 4QEn 1 iii - where one of the four archangels is called שריאל (Sari' el), 'prince of God,' resulting in the Aramaic quartet of Micha'el, Sari'el, Rapha'el and Gabri'el, ${ }^{79}$ in contrast to the Greek grouping of Michael, Uriel (Oủpì̀), Raphael and Gabriel (Charles 1906: 19, 21). ${ }^{80}$ The Ge'ez text opts for గ.C.PA (Surayaal, glossed as Suriel by Knibb), and omits Raphael altogether (Knibb 1978a: 23; cf. Charles 1906: 18):

9.1 And then Michael, Gabriel, Suriel, and Uriel looked down from heaven and saw the mass of blood that was being shed on the earth and all the iniquity that was being done on the earth. 9.2 And they said to one another: 'Let the devastated earth cry out with the sound of their cries unto the gate of heaven. 9.3 And now, to you O holy ones of heaven, the souls of men complain, saying: "Bring our suit before the Most High"” (Knibb 1978b: 84-85; cf. Charles 1912: 20; Black 1985: 29, 129-130; Isaac 1983: 16).

\footnotetext{
78 We might mention here also the occurrence of Sauriel as the angel of death in the Mandaean Book of John, documented in Mayer 1996: 223, 224, 225, 227, 228, 229, 247, 257.

79 Milik 1976: 170, 171, with an extensive discussion in 172-174; see also Black 1985: 129.

${ }^{80}$ For a discussion of how 'the original seven archangels' became 'four presences', see Dix 1927: 238-239.
} 
Milik (1976: 174) concludes that 'as early as the Persian period... Israelites believed in the existence of four archangels whose names and order were: Mîk $k a^{\prime} e l . .$. Śarì' $e l . . . R a f a$ ' $e l . .$. Gabrî' el.' Commenting on שריאל (Sari' el) in 9:1, Milik (1976:172) observes that 'this is the only place in $4 \mathrm{QEn}$ where the name of the second archangel is preserved; it occurs three times in Enoch: here,

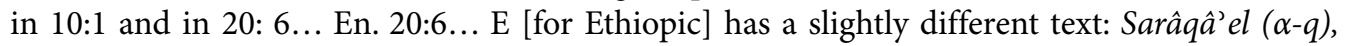
Saraqấ'el $(\beta) .$. '

Milik's conclusion regarding the original names of the fourfold angels is borne out by a section of The War of the Sons of Light against the Sons of Darkness, the so-called 'War Scroll' from Qumran (1QM). In Column IX we read of a 'semicircle with towers and an arc with towers... When the towers go out from the line, (they shall have) one hundred shields on each face of the towers... And on all the shields of the towers they shall write: on the first: «Michael» [מיכאל], [on the second: «Gabriel» [גבריאל], on the third:] «Sariel» [שריאל], on the fourth: «Raphael» [רפלאל]; «Michael» and «Gabriel» on [the right, and «Sariel» and «Raphael» on the left]' (García Martínez and Tigchelaar 1999: 128, 129)]. The Sons of Light are thus aided in their battle against the Sons of Darkness by four monumental amulets sporting the names of Qumran's version of the four archangels.

Regarding the name Baraqiel, I Enoch 6:7 in the Greek has Bapakı' $\lambda$ (Barakiel) in the Cairo Papyrus and Ba $\lambda_{\kappa} ı \dot{\eta} \lambda$ (Balkiel) in Synkellos (Charles 1906: 15); as already noted, the equivalent in the Aramaic is ברקאל (Baraq'el) (Milik 1976: 150, 151, 153, 188, 189). The Greek version of 8:3 (in the Cairo manuscript) has the shortened form pakın $\lambda$ (Rakiel) (Charles 1906: 19), whereas the Aramaic has the full form ברקאל (Baraq'el), the one who 'taught the signs of thunders' (Milik 1976: 157, 158, 170,171). 69:2 is only extant in $\mathrm{Ge}^{\mathrm{c}} \mathrm{ez}$, so neither the Greek nor Aramaic texts are of any help here.

A table outlining the textual variants discussed thus far is perhaps in order. The Aramaic forms are taken from Milik 1976, the Ethiopic ( $\mathrm{Ge}^{\mathrm{c}} \mathrm{ez}$ ) forms from Knibb 1978a and the Greek forms (as found in the Cairo manuscript and Synkellos) from Charles 1906.

\begin{tabular}{|c|c|c|c|}
\hline Verse & Aramaic & Ethiopic $\left(\mathrm{Ge}^{\mathrm{e}} \mathrm{ez}\right)$ & Greek - Cairo; Synkellos \\
\hline $6: 7$ & $\begin{array}{l}\text { לאקרב (Baraq'el,'Lightening } \\
\text { of God') (Milik 1976: 150, 151, } \\
\text { 188, 189) }\end{array}$ & $\begin{array}{l}\text { ก́.中`.PA (Säraqəyaəl = } \\
\text { Saraqael, but interpreted as } \\
\text { Baraqiel) (Knibb 1978a: 16) }\end{array}$ & $\begin{array}{l}B \alpha \rho \alpha \kappa ı \dot{\eta} \lambda ; B \alpha \lambda \kappa \iota \eta \dot{\lambda} \lambda \\
\text { (Charles 1906: 15) }\end{array}$ \\
\hline $6: 7$ & $\begin{array}{l}\text { לאירהש (Sahri'el,'Moon of } \\
\text { God') (Milik 1976: 150, 151, } \\
\text { 188,189) }\end{array}$ & 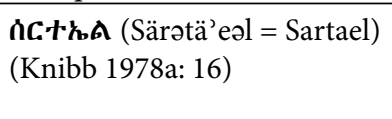 & $\begin{array}{l}\sum \alpha \theta i \eta \dot{\lambda} ; \sum \alpha \rho \iota v \alpha \varsigma \\
(\text { Charles 1906: 15) }\end{array}$ \\
\hline $8: 3$ & $\begin{array}{l}\text { לאקרב (Baraq'el) (Milik 1976: } \\
\text { 157, 158, 170, 171) }\end{array}$ & $\begin{array}{l}\text { IL中9, (Bäräqä‘aəl = } \\
\text { Baraqiel) (Knibb 1978a: 21) }\end{array}$ & 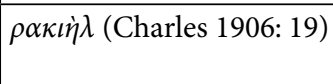 \\
\hline $8: 3$ & $\begin{array}{l}\text { לאירהש (Sahri'el) (Milik 1976: } \\
\text { 157, 158, 170, 171) }\end{array}$ & $\begin{array}{l}\text { hñ.S.h.A ('Äsəradə'iəl = } \\
\text { Asradel) (Knibb 1978a: 22) }\end{array}$ & 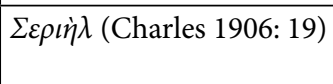 \\
\hline $9: 1$ & $\begin{array}{l}\text { לאירש (Sari'el,'Prince of God') } \\
\text { (Milik 1976: 157, 158, 170, 171) }\end{array}$ & $\begin{array}{l}\text { I.C.PA (Surəyaəl = Suriel) } \\
(\text { Knibb 1978a: } 23)\end{array}$ & 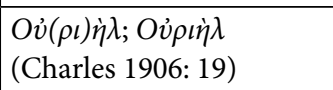 \\
\hline $20: 6$ & no extant fragments & $\begin{array}{l}\text { ก́.\$\$A (Säraqa'eəl = } \\
\text { Saraqael) (Knibb 1978a: 73) }\end{array}$ & $\begin{array}{l}\Sigma \alpha \rho \iota \eta^{\prime} \lambda ; \Sigma \alpha \rho ı \dot{\lambda} \lambda \\
\text { (Charles 1906: 53) }\end{array}$ \\
\hline $69: 2$ & no extant fragments & $\begin{array}{l}\text { กG.\$PA (Bäraqəyaəl = } \\
\text { Baraqiel) (Knibb 1978a: 199) }\end{array}$ & no extant fragments \\
\hline
\end{tabular}


The above table provides some idea, albeit very selective, of the extremely complicated task of unravelling the relationship between angelic names found in the Aramaic, Greek and $\mathrm{Ge}^{\prime} \mathrm{ez}$ versions of I Enoch, a task that is far beyond the scope of this paper.

\section{POSSIBLE ENOCHIC ORIGINS OF THE SYRIAC PASSAGE}

One of the most important questions to arise regarding the Syriac passage under consideration here is how it ended up at Turfan in the form it did. In short, what does the transmission history of this text look like? We will consider this initially here, with reference to the Enoch connection, and later again, when we bring in the aforementioned Jewish magical text (dated from after the time when I Enoch was written).

Although we lack all the information necessary to reconstruct the complete origin story of the Syriac passage in U 328, various possibilities can be considered, all of which depend on the crucial angelic name of Saraqael. In the process, we need to keep in mind the following words, referring in their original context to transmission of texts from Syriac to Ethiopic via Arabic: 'The problem of analyzing the full body of evidence becomes even more acute when we consider the accident of survival... our analysis is only as good as what survives, and what survives is likely only a small fraction of what was once there' (Butts 2020: 55).

It seems almost indisputable that the Syriac passage in U 328 has its ultimate origin in the Aramaic matrix that was so crucial to the culture of the Ancient Near East. Syriac is of course an Aramaic dialect, so a likely explanation is that at least the angelic name (if not the whole passage) was originally transmitted from an Aramaic (or possibly a Syriac) original, rather than being translated from another language ( $\mathrm{Ge}^{\mathrm{c}} \mathrm{ez}$ and Greek being the only other reasonable options).

Admittedly, the name Saraqael occurs in I Enoch solely in the Ge'ez version. However, it seems extremely unlikely that the name found its way from $\mathrm{Ge}^{\text {c }} \mathrm{ez}$ to Syriac, since all known interactions between the two languages involve adoption or adaptation from Syriac to $\mathrm{Ge}^{\prime} \mathrm{ez}$, not vice versa (as a corollary, the same could be said of borrowings between the Church of the East and the Ethiopian Orthodox Church). ${ }^{81}$ In short, there is no evidence of texts moving from Ethiopia into the Syriac-speaking world. It is therefore essentially impossible that the name Saraqael was borrowed directly from the $\mathrm{Ge}^{\mathrm{e}} \mathrm{ez}$ version of I Enoch into the sequence of textual transmission that resulted in our Syriac passage appearing at Turfan.

We can probably also rule out the idea that the name originates in the Greek version, which

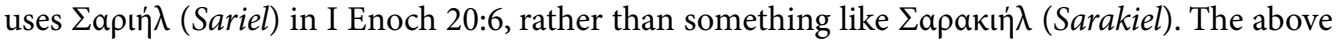
comparison of the Ge'ez and Greek versions of I Enoch shows that there is obviously some sort of link between the names Saraqael and Sariel. However, it seems unlikely that the name would have been expanded from an original Sariel (in Greek) to the longer Saraqael (in Ge'ez); if anything we would expect the name to be shortened from an initial longer form (reflected in the $\mathrm{Ge}^{\mathrm{c}} \mathrm{ez}$ version) to a shorter one (as in the Greek version). The most likely source for the first recorded occurrence of the name in the Ge' ez version of I Enoch is of course the original Aramaic version

${ }^{81}$ On material from the Church of the East that has ended up in the Ethiopian Orthodox biblical commentary tradition, see Lee 2014: 182. As Butts 2020: 25 notes, the interaction 'between Syriac Christianity and Ethiopian Christianity is to be found in the later Solomonic period (starting 1270)' and 'Arabic served as the bridge by which Syriac texts were transmitted into Ethiopic.' 
of the book. Unfortunately, without the crucial Aramaic text of chapter 20, we can do no more than speculate on this matter (and we have no idea what the possible history of the name is prior to its occurrence in I Enoch, if any).

What evidence is there that the name might have come directly from a Syriac source? As noted above, it is likely that the Syriac chronicler Michael the Great had access to 'a Syriac intermediary' text (likely one of the now lost Chronicles of either Jacob of Edessa or John of Litarba) which contained at least some of Annianos' excerpts from I Enoch. Of course, we can only speculate about what that non-extant Syriac text might have contained, although Michael's extract from 6:1-7 concerning the Watchers is one of the passages from I Enoch that is of interest in tracking down the name Saraqael, as noted above.

Citing in part the prevalence of the Syriac term $\sim_{i=,}$, 'watcher, guardian angel, angel' (Payne Smith 1903: 407; Brock and Kiraz 2015: 163; cf. Sokoloff 2009: 1098) (cognate with Aramaic עיר, 'guardian, angel'), Nils Arne Pedersen (2017: 194) suggests that 'Enochic literature was once more widespread in Syriac than often assumed' and that 'Mani may have had access to this literature through Syriac versions, at least partly.' Pedersen (2017: 196-197) also suggests that the supposed Syriac original of the Coptic Manichaean Kephalaia used the term حive (pl. (حن) to designate divine beings that are essentially good. In a similar vein, in a discussion of Manichaean literature and Jewish pseudepigrapha, John Reeves (1994: 183) concludes that 'the early Manichaean community, like its sectarian predecessors, had access to a larger corpus of Jewish pseudepigraphic, and particularly Enochic, literature than do modern scholars today. This brings us to our next excursus.

\section{EXCURSUS ON THE BOOK OF GIANTS}

Here we need to examine another work already mentioned above, which Milik (1976:4) suggests was one of the 'five Aramaic literary works' that made up I Enoch as it was known at Qumran: the Book of Giants, ${ }^{83}$ a work that 'creatively draws upon Enochic traditions about the antediluvian period to fashion a fascinating but poorly preserved narrative about the sons of the watchers' (Goff 2014: 88). The book is so-called because it concerns the giant offspring (often equated with the Nephilim) of 'the sons of God' and 'the daughters of humans' that are mentioned in Genesis 6:4. ${ }^{84}$ As Milik (1976: 298) notes, the Book of Giants develops 'with a considerable number of details, the story of the fallen angels told in the first part of the Ethiopic Enoch (En. 1 to 36)... [the] 'Book of Watchers".

Drawing on the pioneering work of Isaac de Beausobre, a connection between I Enoch and the Book of Giants was made by the Iranist W.B. Henning some time before Aramaic fragments of the

\footnotetext{
${ }^{82}$ Indeed, this Syriac word ( $\kappa^{\prime}$ in in plural) is used by Michael the Great in his version of the story of the Watchers (Brock 1968: 630; see Ibrahim and Brock 2009: [4], right column for the original Syriac text).

${ }^{83}$ In contrast to this view, Black 1985: 10 speculates that 'if the elaboration of the Giants' story belongs to the Watcher legend, then it must be a part of the first 'Book of Enoch' [i.e. the Book of Watchers], not an entire second book.'

${ }^{84}$ On the testimony of the Aramaic fragments of the Book of Giants to the nature of these beings (גברין, Gibborim, as they are called in the fragments), see Fröhlich 2016: 106-111. Note that, although the Nephilim in Genesis 6 'are not explicitly described as the offspring of the sons of God... in the Enochic tradition gibbōrim and naphîlim are synonymous terms for demons who originate from divine beings' (Fröhlich 2016: 113).
} 
Book of Giants were discovered at Qumran and published by Milik. Henning was primarily interested in the Book of Giants because of the role that it played in Manichaean literature, as demonstrated by Middle Persian, Sogdian and Uyghur ${ }^{85}$ fragments of the book found at Turfan. These were edited and translated by Henning, who posited an original 'Aramaic edition' of I Enoch from which Mani translated the Book of Giants into Syriac (1943: 52). ${ }^{86}$

Henning (1943: 55) further traces the transmission history of the Book of Giants as follows: 'From the original Syriac the Greek and Middle Persian versions were made. The Sogdian edition was probably derived from the Middle Persian, the Uygur from the Sogdian... The book may have existed in Coptic... the Arabic version [was] translated from the Middle Persian.' As Henning (1943: 53) notes, 'the story of the fallen angels and their giant sons needed little adaptation to be fitted into Mani's system,' apart from transforming the Watchers into 'those demons that when the world was being constructed had been imprisoned in the skies,' who 'rebelled and were recaptured, but two hundred of them escaped to the earth. ${ }^{87}$ At the same time, as Jens Wilkens (2016: 213) notes, the mythical events from the Qumran version of the Book of Giants 'were subjected to a meticulous Manichaean interpretation, linking the macrocosmic events to microcosmic psychological observations.'

There has been considerable scholarship on the Book of Giants in recent years. ${ }^{88}$ Not surprisingly, many aspects of the work are still open to scholarly debate. For example, there is no current consensus regarding how the extant fragments of the book should be arranged, given that we lack complete manuscripts of the work to guide in the process of reconstructing the original text. ${ }^{89}$ Indeed, the whole relationship of the Book of Giants with the broader Enochic literature has been an important subject of discussion by scholars in the field. Milik (1976: 4) initially suggested that the work now known as I Enoch originally consisted of 'five Aramaic literary works: the Astronomical Book, the Book of Watchers, the Book of Giants, the Book of Dreams, and the Epistle of Enoch. ${ }^{90}$ Scholars have since questioned Milik's idea that the Book of Giants was an original part of the book of Enoch which was later replaced by the Similitudes (also known as the Book of Parables).${ }^{91}$ Having said that, there are undeniable connections between the Book of Giants and the works which make up I Enoch as we now have it, particularly the Book of Watchers (although there are also some important differences between the two). ${ }^{92}$

Of particular interest for our purposes here is the following discussion by Henning: 'The

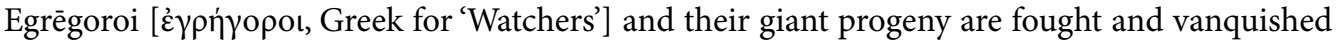
by four archangels: Raphael, Michael, Gabriel, and Istrael (Enoch, 10, 1; or: Uriel, or: Fanuel). In

${ }^{85}$ On the Old Uyghur Version of the Manichaean Book of Giants, see Wilkens 2018. My thanks to Peter Zieme for sharing with me an unpublished list of 'Turkic fragments of the Manichaean Book of Giants' which he has prepared. The list includes fragments previously published by Henning and Wilkens, as well as the unpublished fragment Ot.Ry. 2271.

${ }^{86}$ Since Henning's publication, evidence has emerged that there was also a Parthian version of the Book of Giants (Morano 2009; Sundermann 1973).

87 See also the discussion in Kósa 2016: 147-150.

88 For example, Goff, Stuckenbruck and Morano 2016.

89 See the discussion on 'Methodological Considerations in Reconstructing the Qumran Book of Giants' in Stuckenbruck 2016. For one proposed sequence of the fragments, see Morano 2011.

90 As Milik notes elsewhere on the same page, 'this pentateuchal collection was to be altered during the Christian era by the elimination of the Book of Giants and the insertion of the Book of Parables.'

91 See the discussion in Goff 2014: 63-64.

92 For a helpful discussion of the similarities and differences between the Book of Giants and the Book of Watchers, see Goff 2014: 66-83. 

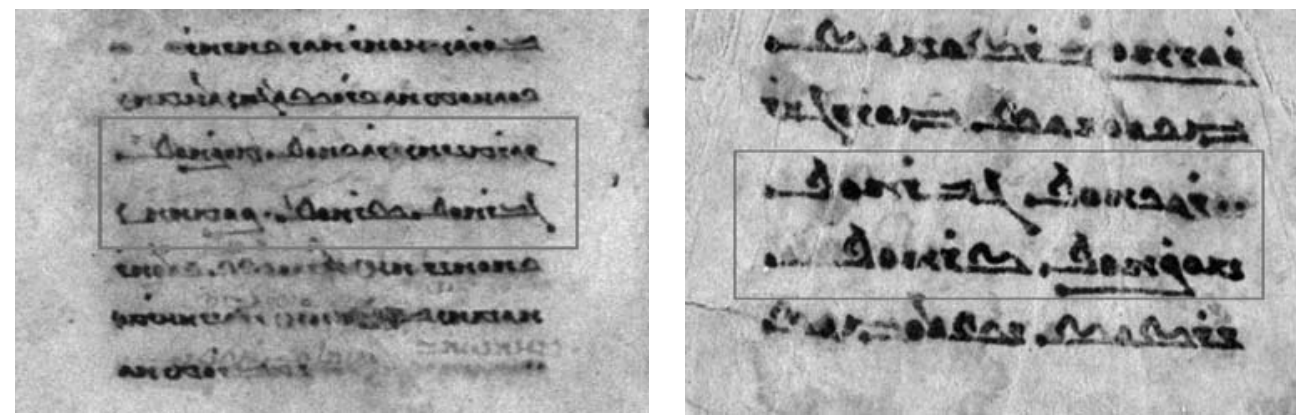

The Four angels listed in Manichaean fragments from Turfan: Fig. 4 = M 4 (left): 'Raphael, Michael, Gabriel and Sariel' and Fig. 5 = M 20 (right): 'Raphael, Gabriel, Michael and Sariel'

the Book of the Giants they are called 'the four angels'. They are frequently invoked by name in Manichaean prayers... as Rwp'yl, Myx'yl, Gbr'yl, and Sr'yl (= Istrael)' (Henning 1943: 54). ${ }^{93}$ In

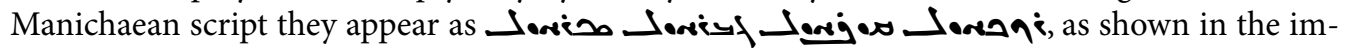
ages above (Figs. 4 and 5).

Unfortunately, the Book of Giants, whether in Aramaic or otherwise, provides no further insight into these angelic names. ${ }^{94}$ However, the angel Baraq'el (ברקאל) does occur in two Aramaic fragments of the Book of Giants found at Qumran, where he is identified as the father of the giant Mahawai (מהוי). In the fragments of the book found at Turfan, Baraq'el's Persianized name is Virôgdâd, meaning 'Given by the lightning,' which enabled Henning to make the equation with Baraq'el even before the Aramaic fragments were discovered (Milik 1976: 300-301,311; Henning 1936a: 4; Henning 1936b: 583-584; Henning 1943: 55, 60, 65).

Although Saraqael is not referred to in the extant fragments of the Book of Giants, the literary remains (whether Aramaic or Manichaean) are so fragmentary that we should not discount the possibility that the name was included somewhere in the original Aramaic version and therefore perhaps in its Manichaean form as well. It is also very interesting that Baraqiel is mentioned by name and that the angel called Sariel elsewhere in Manichaean texts is alluded to, at least as one of the 'four angels.' As we can see from the table above, particularly with reference to I Enoch 6:7 and 20:6, there is obvious confusion between these three names - Baraqiel, Saraqael and Sariel - which might give us pause as we consider U 328. More specifically, could the Book of Giants, obviously known at Turfan, have played any role in the transmission of the name Saraqael from its original Aramaic context to a text intended to help Uyghur Christians with such day-to-day tasks as enclosing horses in a pen?

Of particular interest here is a word in our text that deserves some comment. Saraqael is described as lated word, 살, 'ruler' (in both singular and plural forms) is found in fragments $1+3$ (flesh side)

${ }_{93}$ On the four angels in Middle Persian and Parthian Manichaean texts from Turfan, specifically hymns and prayers which are 'on the verge of being incantations in the proper sense, along with amulets and spells proper, see Morano 2004: 221, 222, 224. On the occurrence of these four angelic names in a Chinese Manichaean text, see Kósa 2016: 155-157.

${ }_{94}$ Milik 1976: 316 suggests that 'Manichaean tradition, drawing on the Book of Giants, preserved the name of the archangel Śarî' el more faithfully than Greek and Ethiopic tradition,' a statement that our Syriac text from Turfan does not necessarily support. 
from P 22364 in the Berlin Papyrus Collection. ${ }^{95}$ These fragments contain Syriac text written in Manichaean script; although there is no record of their provenance, 'it is almost certain that these fragments are Manichaean, probably coming 'from a codex' which was 'originally written in Egypt by Syriac-speaking Manichaeans' or 'in the Syrian region and later imported to Egypt' (Pedersen 2013: 18). Although the P 22364 fragments are small, they contain 'a very rare attestation of an expression which seems to have been dear to Mani himself' (Pedersen 2013: 206), suggesting that they preserve one of Mani's own writings (as opposed to those composed by the Manichaean community after his death).

In considering the textual origins of these fragments, Pedersen (2013:214) wonders 'whether P 22364 could contain fragments of Mani's Book of the Giants.' Although a definitive answer cannot be found, he concludes that 'it is not impossible that they [fragments 1 and 3] were smaller unknown parts of the longer story about the watchers and the giants' (Pedersen 2013: 219). Moreover, the connection of Saraqael with the verb $\forall$, 'to bear rule, bear sway, have the mastery, prevail' (Payne Smith 1903: 579; Brock and Kiraz 2015: 222; cf. Sokoloff 2009: 1562) calls to mind the use of rever, 'a taskmaster; a ruler, leader, governor, prefect, prince' (Payne Smith 1903: 580; Brock and Kiraz 2015: 222; cf. Sokoloff 2009: 1565) in the Peshitta text of the Hebrew Bible, particularly in Dan. 10:13, 20, 21, where it is used 'about the angelic ruler of Persia... of the Greeks... and about Michael, "your ruler"' - the word in the Hebrew text of Daniel is שר, 'prince' (Pedersen 2013: 219). And so we are back to the description of Saraqael in our text as מ

We thus have similar phraseology being used in U 328 and Manichaean texts, including some which may be connected with the Book of Giants, albeit possibly in a tangential way. This in turn raises the question of what possible evidence we have that the Book of Giants ever existed in some form in Syriac, a parallel question to that which was raised above regarding the possible existence of a Syriac version of I Enoch. We can gain some insight into the Syriac Book of Giants question by examining what various Syriac writers have said.

The first and most important Syriac writer in this regard is Ephrem the Syrian (d. 373). We can be quite confident that Ephrem, living only a century after Mani (d. 274 or 277), read Manichaean works in Syriac. As John Reeves (1997: 219) notes, 'the language in which Mani originally prepared most of his "canonical" writings was Syriac... the most likely sources preserving Manichaean terminology in its mother tongue are the Syriac writings of Syrian heresiologists, pre-eminent among whom are Ephrem and Theodore bar Konai.' Amongst the Manichaean works that he consulted, Ephrem seems to have been familiar with the Book of Giants, although the allusions are admittedly rather faint. ${ }^{96}$ The writings of Theodore also suggest a familiarity with the same work (Reeves 1991).

Reeves (2016: 210,201) has also argued convincingly that Jacob of Edessa 'may be indebted to some form of the Book of Giants, even in its Manichaean version' for comments that he makes regarding 'heretical and erring persons of a pagan orientation' who 'composed poetical fables about them [the giants] which were full of foolishness and error.' Although Jacob lived several centuries after the time of Mani, it is not inconceivable that he too consulted Manichaean works in Syriac; if not, it is unclear in what language Jacob would have become familiar with the Book of Giants (certainly not in any of its iterations in Iranian or Turkic languages).

95 Text and translation can be found in Pedersen 2013: 70, 71

96 As documented in Ruani 2013. 
In considering what sources are currently available (as opposed to in the past), Reeves (1994: 183) concludes that 'the early Manichaean community [and, we might add, other communities at the time]... had access to a larger corpus of Jewish pseudepigraphic, and particularly Enochic, literature than do modern scholars today. Whether transmitted through a network of Aramaic and Syriac-speaking (non-Manichaean) communities or directly through the Manichaean community in Turfan, we cannot rule out the possibility that non-extant Enochic literature may have preserved the angelic name found in our passage.

So, is it possible that Christians at Turfan, whether knowingly or unknowingly, learned of Saraqael from Manichaean sources? To be sure, there must have been interaction between Christians and Manichaeans in Turfan - two missionary religions living in such close contact can hardly have avoided each other - but there is precious little evidence of such interaction, apart from a Christian tract directed against the Manichaeans and a Manichaean one against the Christians (Sims-Williams 2003; Sundermann 2009). In the end, we cannot know what (if any) role Manichaeism played in the evolution of the Syriac passage found in U 328, but the possibility of Turfan Christians being familiar with the Book of Giants should not be ruled out. Another possible explanation involving Manichaean connections concerns the Elkasites (the Judeo-Christian sect that Mani grew up in ${ }^{97}$ ). Perhaps they, or one of the other Judeo-Christian groups in Mesopotamia at the time, were conduits for ideas and texts (possibly including the Book of Giants), which Mani adopted and adapted for his own purposes. ${ }^{98}$

It is not hard to imagine traditions concerning Saraqael and the other angels mentioned above, borrowed from I Enoch for the purposes of prayers and incantations, ending up in Mesopotamia during the time when Mani was preaching, then being used by various groups with Christian connections (including the Elkasites). But what other evidence is there for these speculations?

\section{THE ANGELIC NAME SARAQAEL IN A BABYLONIAN JEWISH ARAMAIC MAGICAL TEXT}

We come now to the second occurrence of the name Saraqael in an extant text, namely the Pishra de-Rabbi Hanina ben Dosa (פישרא דרבי חנינא בן דוסא), the 'Spell-Loosener of Rabbi Hanina ben Dosa. ${ }^{99}$ This is a magical text - 'one of the more popular Jewish magical texts of Late Antiquity and the Middle Ages' (Bohak 2019: 357) - written in Babylonian Jewish Aramaic and probably to be dated to the time when the Babylonian Talmud was composed (ca. 500). The earliest manuscripts containing it are part of the Cairo Genizah collection (Bohak 2019: 357). Like most such texts, it is concerned primarily with the health and protection of the person for whose benefit it was recited. It 'displays several close parallels with some of the Aramaic incantation bowls from Sasanian Mesopotamia' (Bohak 2019: 356), to be discussed below, and is also similar to 'some of the Akkadian anti-witchcraft texts,' resulting in 'a slightly Judaized version of a much older, "pagan," spell against witches and witchcraft' (Bohak 2019: 356).

\footnotetext{
97 On Mani and his teachings, see Piras 2005. On Alchasai and his teachings, see Asmussen 1985.

98 See discussion in Pedersen 2017: 187-188, as well as Reeves 2016: 210-211.

99 On this text in general, see Bohak 2013; for a specific iteration of it in a twentieth century amulet from Morocco, see Bohak 2019.
} 
Pishra (פישרא) comes from the Aramaic verbal stem $\sqrt{ }$ PŠR (פשר), which in various forms can mean 'to melt, dissolve... to separate, tear loose, disengage...' (Jastrow 1903: 1248-1249). Although the noun pishra itself usually refers to 'solution, interpretation... dissolved food, cud... thawing snow' (Jastrow 1903: 1172), in the context of a magical text it means a 'witchcraft-loosening spell' (Bohak 2019: 351). As Bohak (2019: 357) notes, in this sense it is 'attested already in the Akkadian language, and is well attested in the Babylonian Aramaic incantation bowls.'

The Pishra de-Rabbi Hanina ben Dosa consists of several sections, one of which is a list of 'all the days of the week, all the days of the month, all the months of the year and the twelve signs of the zodiac, and all seven planetary hours, on which' magic rituals 'may have been carried out against [the client for whom the text was personalized] and the name of the angel who would annul them' (Bohak 2019: 356). In this list we find the following text (kindly supplied to me by Gideon Bohak): ואם בתרין בירחא עבדו ליה סרקיאל ישרי ויפשר ליה (And if on the second of the month they performed (witchcraft) on him, Saraqiel [סרקיה : בירזי] will loosen and unbind him.'

So here we have another instance of the name Saraqael, this time clearly originating in Mesopotamia. Its potential connection with the other iterations of the name will be explored below. Before moving on to look at amulets and incantation bowls more broadly, we should note here Bohak's observation that 'some manuscripts [of the Pishra de-Rabbi Hanina ben Dosa] read Barqiel, ברקיאל, instead of Sarqiel... such variae lectiones are common in the magical texts. ${ }^{100}$ Indeed this alternation between the two names can be seen in the Cairo Genizah text Taylor-Schechter K 2.3, part of the Cambridge collection. ${ }^{101}$ We have of course already seen the curious relationship between these two names in I Enoch.

\section{POSSIBLE CONNECTIONS WITH OTHER AMULETS AND INCANTATION BOWLS}

There are also possible connections that can be made between the angelic names considered above (Baraqiel, Saraqael and Sariel) and those found on various incantation bowls and amulets ${ }^{102}$ inscribed in Aramaic dialects and discovered chiefly in Mesopotamia, Iran and Israel/Palestine. Incantations are essentially 'rhythmically organized words of power that are chanted, spoken, or written to accomplish a desired goal by binding spiritual powers to act in a favorable way' (Ludwig 2005: 4406). The practice of placing 'earthenware bowls, inscribed with ink, usually on the concave side in spiral concentric circles' (Naveh and Shaked 1985: 13) upside down and burying them somewhere in the house corresponds to late Sassanian times; most bowls have been dated to the sixth or seventh centuries. The incantations on these bowls are typically inscribed in Jewish Aramaic, Mandaean or Syriac ${ }^{103}$ and those who commissioned their making included Jews, Christians, Zoroastrians, Mandaeans, pagans and others (indeed, in many cases, the inscriptions on the bowls cross religious boundaries).

\footnotetext{
100 Personal correspondence, Oct. 6, 2020.

101 Again, I am indebted to Gideon Bohak for this information. He notes specifically that 'you get the reading סרקיאל, and a small correction mark above it, which refers you to the right of the page, where the alternative reading ברקיאל is offered' (personal correspondence, Oct. 25, 2020).

102 As noted in Naveh and Shaked 1985: 13, 'Aramaic magic literature continues Assyrian, Babylonian and Egyptian magic, and is closely related to the rich literature of magic and incantations in Greek, known to us chiefly from Egyptian papyri.'

103 On the Syriac bowls, particularly their linguistic features, see van Rompay 1990.
} 
Theories abound as to the purpose of these incantation bowls (see Isbell 1978: 7-10), but in general they are viewed as a means of encapsulating in written form charms that have been ritually spoken in order to protect against the activities of demons and evil spirits. In them, malevolent powers are bound, banned and cast down or cast out, whereas the clients for whom the bowls are prepared (along with their homes and property) are sealed, guarded and established. The upside-down position of many incantation bowls 'has led scholars to assume that they may have served as traps for demons, being meant to keep the evil spirits imprisoned inside them' (Naveh and Shaked 1985: 15), although there are also other theories of how the bowls 'worked.' Incantation bowls often feature standard formulaic texts which function as templates into which names and other personal data can be inserted (see Hunter 2002).

We do not find Saraqael definitively mentioned in any of the texts addressed in this section. However, there are instances of Baraqiel and Sariel on the amulets and incantation bowls discussed here. Thus, on a bowl written in Proto-Manichaean Syriac (which James Montgomery refers to, perhaps naively, as 'for the first time a case of Christian usage of the ancient practice of bowl incantation'), a Syriac inscription ${ }^{104}$ includes the following phrase: 'In the name of these angels-faithful are they-Michael the angel and Ruphael the angel-warders are they: Yohabiel and Barakiel [Montgomery's text in Hebrew characters actually reads ברקיאיל 'Baraqiel,' not ברכיאיל, 'Barakiel'] the angel. The house-do you angels by your stroke protect my house' (Montgomery 1918: 138). I mention this text for two reasons. First we have a variation on the archangelic quartet which includes Baraqiel, one of the rebellious angels who (as noted above) may have been confused with Saraqael in the Ge'ez text of I Enoch. Second, we may have here another instance of some form of interaction between Christianity and Manichaeism. True, we do not know enough about how and by whom Proto-Manichaean Syriac was used, but it may well be that boundaries between these two faiths in the beginning were much less impermeable than later on, especially when dealing with magical texts.

Baraqiel's name also occurs in Judeo-Aramaic magical texts, including an incantation bowl in the British Museum, where ברקיאיל is included in a list of nine angels amongst whom the client, one Maperoz son of Hindu (פפירוז בר הינדו) 'shall dwell' (Segal and Hunter 2000: 52) ${ }^{105}$ and an amulet found in Israel, which invokes the names 'Barqiel, Uriel, Milhamiel.' Interestingly, the first of the three names in the text is rendered בר)[ר)קיאל]; is it possible that the first letter could be 0 , giving the name 'Sarqiel/Saraqael' (Naveh and Shaked 1985: 91)?

Again, in a Syriac amulet which is probably of Iranian provenance, the name of 'Barqiel' (כin) occurs in the first line, unfortunately by itself, but seemingly at the head of a list of angelic names, based on the following fragmentary lines (Gignoux 1987: 11). In a Syriac amulet roll which is also likely Iranian in origin and probably from the sixth-seventh century, the text exor-

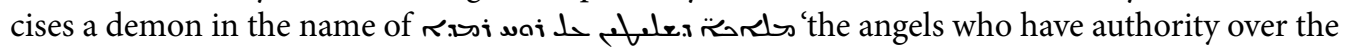

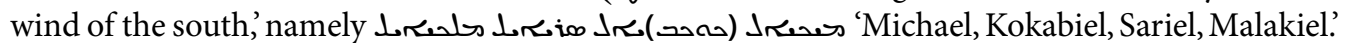
Here, in addition to Sariel, we also find Michael from amongst the 'four angels' discussed above

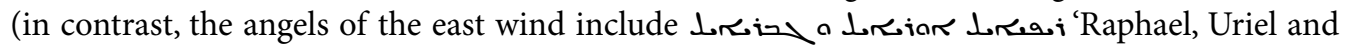

104 Two different Syriac scripts were utilized on incantation bowls: the script used for classical Syriac (the dialect of Edessa) and the so-called Proto-Manichaean script.

105 See also Segal and Hunter 2000: 62, where Barqiel (ברקיאל) occurs in a list of seven angels invoked to open the gates of all the children of Adam and Eve to the gates' of the client, who seems to be a shopkeeper, and Segal and Hunter 2000: 91, which again includes Barqiel (ברקיאל) in a list of seven angels called upon to bind and seal evil spirits away from the house of the client. 
Gabriel'). Kokabiel's presence in this list is somewhat surprising - given his role in the angelic rebellion discussed in I Enoch chapters 6,8 and 69 - but a reminder that most amulet writers probably had not read Enoch and that lists of angels became hopelessly convoluted and confused over time (Gignoux 1987: 50, 51).

We might also note occurrences of two different variations of the name Sariel which occur on published amulets. On an undated Babylonian Jewish Aramaic amulet we encounter the same variation of the name that occurs in the Ge'ez version of I Enoch 9:1 - Suriel (סוריאל) (Geller 1997: 333, 334). In Add. 3086, an eighteenth century Syriac manuscript kept at the University of Cambridge Library (Wright 1901: 1214-1215), we find an amulet for 'binding the tongue of the ruler' which includes a list of no fewer than 36 angels, including two occurrences of Sahriel (שהריאל) (שחוֹ) , obviously a reference to the aforementioned Sahri'el on the Aramaic fragments of I Enoch from Qumran (Gollancz 1912: 1xxv, 79).

The names of the four archangels also occur on incantation bowls, as an example in Aramaic script published by Montgomery (1913: 183) makes plain, when it mentions 'And in the name of Michael and Gabriel [סיכאיל וגבריאל]... in the name of Sariel [שריאל], in the name of Seraphiel, Suriel and Sarsamiel, Gadriel, Peniel, Nahriel.' Perhaps the name of Raphael was originally written in the lacuna represented by the ellipsis. Finally, 'Sariel the angel and Barakiel the angel' are mentioned together twice in the context of a counter-spell in which curses are sent back to those who pronounced them, found on a sixth or seventh century Mandaic incantation bowl from Seleucia-Ctesiphon now housed in the Kelsey Museum of Archaeology in Ann Arbor, MI (accession number 19504). ${ }^{106}$ It is unclear from the online source if the second name in the original is BRKY'L or BRQY'L.

Admittedly, the above survey of extant amulet and incantation bowl texts is anything but conclusive in the search for origins of the angelic name on U 328. Apart from the Pishra de-Rabbi Hanina ben Dosa, we have no clear occurrences of the name Saraqael in any of these magical texts.

\section{FINAL CONCLUSIONS}

And now to assimilate and synthesize all the data presented above. The manuscript fragment U 328 clearly demonstrates the way that Central Asian Christians, at least at Turfan, were quite at home with amulets that appealed to the pragmatic concerns of life in the Central Asian milieu. Alongside texts that would be considered by the Church of the East to be more theologically orthodox (biblical, liturgical, hagiographical and otherwise), texts like U 328 were utilized in order to obtain the aid of spiritual powers, including angels, in discerning the future or accomplishing specific tasks.

Moreover, members of the Turfan Christian community were almost certainly assisted in the use of magical (or rather para-liturgical) texts by the clergy, those in the community who had the greatest knowledge of the Syriac language and its various literary expressions. Indeed, these texts could not have been prepared without the explicit participation of Christian clerics or monks. But we still have not answered the crucial question of how the embedded Syriac passage reached Turfan.

106 http://www.faculty.umb.edu/gary_zabel/Courses/Phil\%20281b/Philosophy\%20of\%20Magic/Arcana/ Neoplatonism/def2.display.html. 
We must start with the three texts in which the angel Saraqael's name appears, since that name provides the most logical pathway towards discerning the origins of the Syriac passage in U 328 . As noted above, there can be little doubt that those origins lie within the Aramaic matrix which informed so much of the culture of the Near East, particularly its linguistic and literary aspects. Certainly this is true of the first two of those three texts, namely the book of I Enoch and the Pishra de-Rabbi Hanina ben Dosa (the third text being U 328 itself). We might imagine something like the following unfolding over the course of multiple centuries.

Although we lack definitive proof of this, it is certainly feasible that the (non-extant) Aramaic text of I Enoch 20:6 had סרקיאל (Saraqiel) or something very similar to it as the name of the fifth Watcher. This would certainly explain the form Säraqa'eal that we find in the Ge'ez version of that verse; the Greek form Sapın' $\lambda$ (Sariel) could also be derived from it, as a result of simply eliding the third consonant $p$ in the original Aramaic.

The next step is unclear, but again we might imagine the name being borrowed from I Enoch into the magical literature of the Near East and passed on into various streams of that literature, one of them being the Babylonian Jewish Aramaic magical literature which produced the Pishra de-Rabbi Hanina ben Dosa. The Syriac passage in U 328 could then have reached Turfan through a number of different avenues, but two (or possibly three) options stand out as most likely.

The first avenue would involve amulets from Mesopotamia that were carried eastward by Syriac Christians, whether monks, merchants or others. It is of course not clear when or how our text would have reached its final form - did the angel Saraqael arrive in Turfan in the textual garb we find in U 328 or was his name brought courtesy of another text, from which he was borrowed into the amulet for capturing horses?

We also cannot know at what point the amuletic text would have been translated from Aramaic script to Syriac script (a relatively easy process, given that Syriac is an Aramaic dialect), but presumably this would have happened in Mesopotamia. As outlined above, it remains questionable whether there was ever a complete Syriac text of I Enoch. We have no idea how extensive the original text was that Michael the Great quoted from; did it cover the whole of I Enoch or just portions of Chapter 6 ? Nor do we know whether it would have been accessible to Christians living in Mesopotamia, particularly given the confessional divide between the latter, members of the Church of the East, and the Syrian Orthodox that Michael the Great and his forbearers (notably Jacob of Edessa and John of Litarba) belonged to. In light of these considerations, I consider it unlikely that the text which Michael had access to could have played any role in the transmission story we are concerned with here.

The second avenue by which the name Saraqael might have reached Turfan is more speculative, but still not outside the bounds of possibility. This would involve Saraqael being mentioned in a non-extant section of the original Aramaic Book of Giants, from which it would have passed into the Syriac version that Mani propagated. Given the presence of Judeo-Christian sects like the Elkasites in Mesopotamia at the time and assuming that Enochic material was popular among such groups, it is possible that Mani may have heard the name Saraqael at some point, whether in the Book of Watchers or the Book of Giants.

If a Syriac (or even Middle Persian) version of the latter were brought to Turfan, it would have conceivably been accessible to the Christian clergy there - in addition to the many Syriac fragments found at Turfan, remnants of a Middle Persian Psalter were also discovered there (Andreas 1910). Of course, this implies that Christians would have been comfortable borrowing material 
from a Manichaean source, which is not at all apparent. Thus, the Book of Giants route is less likely than the amulet route.

A third (also less likely) option is that I Enoch itself was directly accessible to the Turfan Christians (rather than the name Saraqael being mediated through an amulet which had its origins in Mesopotamia). This would require the text of I Enoch to have migrated to Turfan in a form that was understandable to the Christians there. The most likely linguistic options would have been Syriac, Sogdian or Middle Persian. However, as noted above, there is no clear evidence of the complete text of I Enoch having been translated into any of these languages, so this explanation also seems highly speculative.

More than once we have noted above the interaction and indeed alternation between the names Saraqael and Baraqiel in the texts addressed in this study. Specifically, both the Ge'ez version of I Enoch 6:7 and extant examples of the Pishra de-Rabbi Hanina ben Dosa exhibit the textual variants Saraqael and Baraqiel. This is perhaps merely coincidental, but it is nonetheless interesting that one of the seven holy archangels could be confused with one of the rebellious angels that corrupted humankind, according to I Enoch. We are also left with the curious fact that Saraqael's name literally translates as the enigmatic phrase 'comb of God,' whereas Baraqiel's name has the much more dignified meaning 'thunder of God.' But this is a matter beyond the scope of the current study.

With Sariel we have an angelic name which both stands on its own in Aramaic (in I Enoch 9:1) and exhibits confusion with other Aramaic names (notably Saraqael and Sahriel, in I Enoch 20:6, 6:7 and 8:3) when translated into Greek. It is again unclear how much if any influence this may have had on the transmission history of our Syriac passage, but at the least, it appears that Saraqael was an alternate name of one of the four (or seven) archangels; in the form Sariel he appears in the Dead Sea Scrolls, on incantation bowls, and in Manichaean texts.

In the end, we can only speculate about how the Syriac passage in U 328 ended up in a collection of Uyghur magical texts in Turfan. There is still much that we do not know about the transmission of religious ideas along the Silk Road network and the interaction between different religious traditions in places like Turfan. Let us hope that other texts preserving Enochic material will be unearthed - whether in the Middle East or Central Asia - to shed light on the questions raised by our text.

\section{BIBLIOGRAPHY}

\section{Primary sources}

Adler, William and Paul Tuffin 2002. The Chronography of George Synkellos: A Byzantine Chronicle of Universal History from the Creation. Oxford: Oxford University Press.

BAsset, René 1915. Le Synaxaire Arabe Jacobite (Rédaction Copte) III: Les Mois de Toubeh et d'Amghir [Patrologia Orientalis, Tom. XI, Fasc. 5]. Paris: Firmin-Didot.

BLACK, Matthew 1985. The Book of Enoch or I Enoch: a New English Edition [Studia in Veteris Testamenti Pseudepigrapha 7]. Leiden: E. J. Brill.

Budge, Ernest A. Wallis 1893. The Book of Governors: The Historia Monastica of Thomas Bishop of Margâ A.D. 840, Vol. II: The English Translation. London: Kegan Paul, Trench, Trübner and Co. 
Budge, Ernest A. Wallis 1913. Syrian Anatomy, Pathology and Therapeutics or 'The Book of Medicines,' Vol. II: English Translation, Index. Oxford: Oxford University Press.

Снавот, Jean-Baptiste 1899-1900. Chronique de Michel le Syrien, Patriarche Jacobite d'Antioche 1166-1199, Vol. I. Paris: Ernest Leroux.

Charles, R. H. 1893. The Book of Enoch. Oxford: Clarendon Press.

Charles, R. H. 1906. The Ethiopic version of the book of Enoch [Anecdota Oxoniensia, Semitic Series, Part 11]. Oxford: Clarendon.

Charles, R. H. 1912. The Book of Enoch or I Enoch. Oxford: Clarendon.

Dillmann, August 1853. Das Buch Henoch. Leipzig: Fr. Chr. Wilh. Vogel.

García Martínez, Florentino and Eibert J.C. TigchelaAr 1999. The Dead Sea Scrolls: Study Edition. Leiden: Brill.

Gignoux, Philippe 1987. Incantations magiques syriaques. Louvain: E. Peeters.

Gollancz, Hermann 1912. The Book of Protection, Being a Collection of Charms. London: Oxford University Press.

Ibrahim, Gregorios Yohanna and Sebastian P. Brock 2009. The Edessa-Aleppo Syriac Codex of the Chronicle of Michael the Great (Texts and Translations of the Chronicle of Michael the Great). Piscataway, NJ: Gorgias Press.

IsAAC, Ephraim 1983. '1 (Ethiopic Apocalypse of) Enoch: a New Translation and Introduction. In: James H. Charlesworth (ed.) The Old Testament Pseudepigrapha. Vol. 1. Garden City, NY: Doubleday and Company, 5-89.

James, Montague Rhodes 1920. The Lost Apocrypha of the Old Testament. London: Society for Promoting Christian Knowledge.

Kitchen, Robert A. and M. F. G. Parmentier 2004. The Book of Steps: the Syriac Liber Graduum. Kalamazoo: Cistercian Publications.

KNIBB, Michael A. 1978a. The Ethiopic Book of Enoch: a new edition in the light of the Aramaic Dead Sea fragments, Vol. 1: Text and Apparatus. Oxford: Clarendon.

KNiBB, Michael A. 1978b. The Ethiopic Book of Enoch: a new edition in the light of the Aramaic Dead Sea fragments, Vol. 2: Introduction, Translation and Commentary. Oxford: Clarendon.

Lunt, Horace 1985. 'Ladder of Jacob: a New Translation and Introduction.' In: James H. Charlesworth (ed.) The Old Testament Pseudepigrapha. Vol. 2. Garden City, NY: Doubleday and Company, 401-412.

MiLıк, J. T. 1976. The Books of Enoch: Aramaic fragments of Qumrân Cave 4. Oxford: Clarendon.

Montgomery, James A. 1913. Aramaic Incantation Texts from Nippur. Philadelphia: University Museum.

Naven, Joseph and Shaul Shaked 1985. Amulets and Magic Bowls: Aramaic Incantations of Late Antiquity. Jerusalem and Leiden: The Magnes Press and E. J. Brill.

NAveH, Joseph and Shaul Shaked 1993. Magic Spells and Formulae: Aramaic Incantations of Late Antiquity. Jerusalem: The Magnes Press.

VAnderKam, James C. 1989. The Book of Jubilees [Corpus Scriptorum Christianorum Orientalium 511/ Aeth. 88]. Louvain: E. Peeters.

\section{Secondary sources}

AdLeR, William 1989. Time Immemorial: Archaic History and Its Sources in Christian Chronography from Julius Africanus to George Syncellus. Washington, DC: Dumbarton Oaks Research Library and Collection.

Adler, William 1994. 'Jacob of Edessa and the Jewish Pseudepigrapha in Syriac Chronography.' In: John C. Reeves (ed.) Tracing the Threads: Studies in the Vitality of Jewish Pseudepigrapha [Early Judaism and its Literature, No. 6]. Atlanta, GA: Scholars Press, 143-171. 
Alkıм, V. Bahadır et al. 1998. Türkçe-İngilizce Redhouse sözlüğ̈̈ (17 ed.). İstanbul: Sev Yayıncılık.

Andreas, Friedrich Carl 1910. 'Bruchstücke einer Pehlewi-Übersetzung der Psalmen aus der Sassanidenzeit.' Sitzungsberichte der Königlich Preussischen Akademie der Wissenschaften 1910: 869-872.

Arnold, John Charles 2013. The Footprints of Michael the Archangel: The Formation and Diffusion of a Saintly Cult, c. 300-c. 800. New York: Palgrave Macmillan.

Asmussen, J. P. 1985. 'Alchasai.' In: Encyclopoedia Iranica, Vol. I, 824-825.

BADGER, George P. 1852. The Nestorians and Their Rituals, Vol. I. London: Joseph Masters.

Barton, George A. 1912. 'The Origin of the Names of Angels and Demons in the Extra-Canonical Apocalyptic Literature to 100 A.D.' Journal of Biblical Literature 31/4: 156-167.

BenZ, Frank L. 1972. Personal Names in the Phoenician and Punic Inscriptions: A Catalog, Grammatical Study and Glossary of Elements [Studia Pohl 8]. Rome: Biblical Institute Press.

Berlin-Brandenburg Academy of Sciences and Humanities 2007. Turfan Studies. Berlin: Berlin-Brandenburg Academy of Sciences and Humanities.

Bhayro, Siam 2001.'A Karshuni (Christian Arabic) Account of the Descent of the Watchers.' In: Ada Rapoport-Albert and Gillian Greenberg (eds.) Biblical Hebrew, Biblical Texts: Essays in Memory of Michael P. Weitzman. Sheffield: Sheffield Academic Press, 365-374.

Bhay ro, Siam 2015. 'Divorcing a Demon: Incantation Bowls and BT Gițin 85b.' In: M. J. Geller (ed.) The Archaeology and Material Culture of the Babylonian Talmud. Leiden and Boston: Brill, 121-132.

Bонак, Gideon 2009. 'Prolegomena to the Study of the Jewish Magical Tradition.' Currents in Biblical Research 8/1: 107-150.

Bонак, Gideon 2013. 'Pishra de-Rabbi Hanina ben Dosa.' In: Roger S. Bagnall (ed.-in-chief) The Encyclopedia of Ancient History. Vol. 9. Malden, MA: Wiley-Blackwell, 5337.

Вонак, Gideon 2019. 'An Ancient Babylonian Text on a Modern Jewish Amulet.' In: Shalom SABar, Emile Schrijver and Falk Wiesemann (eds.) Windows on Jewish Worlds: Essays in Honor of William Gross Collector of Judaica, on the Occasion of his Eightieth Birthday. Zutphen: Walburg Pers, 350-361.

Boyarin, Daniel 2007. 'Watchers.' In: Fred Skolnik (ed.-in-chief) Encyclopaedia Judaica (2nd ed.), Vol. 20. Detroit et al.: Thomson Gale, 688.

Brock, Sebastian P. 1968. 'A Fragment of Enoch in Syriac.' Journal of Theological Studies 19 (N.S.): 626-631.

Brock, Sebastian P. 2011. 'Bardaișan.' In: Sebastian P. Brock (ed.) Gorgias Encyclopedic Dictionary of the Syriac Heritage. Piscataway, NJ: Gorgias Press, 56-57.

Brock, Sebastian P. and George Kiraz 2015. Gorgias Concise Syriac-English, English-Syriac Dictionary. Piscataway, NJ: Gorgias Press.

Budge, Ernest A. Wallis 1930. Amulets and superstitions. London: Oxford University Press.

Butts, Aaron M. 2020. 'From Syriac to Arabic to Ethiopic: Loci of Change in Transmission.' In: R. B. FinAzzi et al. (eds.) Circolazione di testi e superamento delle barriere linguistiche e culturali nelle tradizioni orientali [Orientalia Ambrosiana 7]. Milan: Biblioteca Ambrosiana - Centro Ambrosiano, 21-57.

Clauson, Gerard 1972. An Etymological Dictionary of Pre-Thirteenth Century Turkish. Oxford: Clarendon Press.

Coblentz Bautch, Kelley 2019. 'Book of the Watchers.' In: Daniel M. Gurtner and Loren T. StuckenBRUCK (eds.) T®T Clark Encyclopaedia of Second Temple Judaism, Vol. 1. London: T\&T Clark, 164-168.

Collins, John J. 1989. The Apocalyptic Imagination: An Introduction to the Jewish Matrix of Christianity. New York: Crossroad.

Davidson, Gustav 1971. A Dictionary of Angels, Including the Fallen Angels. New York and London: Free Press and Collier-Macmillan. 
Dickens, Mark 2009a. 'Multilingual Christian Manuscripts from Turfan.' Journal of the Canadian Society for Syriac Studies 9: 22-42.

Dickens, Mark 2009b. 'Syriac Gravestones in the Tashkent History Museum. In: Dietmar W. WinkLer and Tang Li (eds.) Hidden Treasures and Intercultural Encounters: Studies on East Syriac Christianity in China and Central Asia [Orientalia - Patristica - Oecumenica, Vol. 1]. Wien: LIT Verlag, 13-49.

Dickens, Mark 2013a. 'Scribal Practices in the Turfan Christian Community.' Journal of the Canadian Society for Syriac Studies 13: 3-28.

Dickens, Mark 2013b. 'Syro-Uigurica II: Syriac Passages in U 338 from Turfan.' Hugoye 16/2: 301-324.

Dickens, Mark 2018. 'Syriac Christianity in Central Asia.' In: Daniel KIng (ed.) The Syriac World. Abingdon: Routledge, 583-624.

Dickens, Mark 2020. Echoes of a Forgotten Presence: Reconstructing the History of the Church of the East in Central Asia [Orientalia - Patristica - Oecumenica, Vol. 15]. Berlin: LIT Verlag.

Dickens, Mark and Peter Zieme 2014. 'Syro-Uigurica I: A Syriac Psalter in Uyghur Script from Turfan. In: Johannes den Heijer, Andrea B. Schmidt and Tamara Pataridze (eds.) Scripts Beyond Borders. A Survey of Allographic Traditions in the Euro-Mediterranean World [Publications de l'Institut Orientaliste de Louvain, Vol. 62]. Leuven: Peeters, 291-328.

Dix, G. H. 1927.'The Seven Archangels and the Seven Spirits: A Study in the Origin, Development, and Messianic Associations of the Two Themes. Journal of Theological Studies 28/111: 233-250.

ERdAL, Marcel 1991. Old Turkic Word Formation: a Functional Approach to the Lexicon, Vol. 1 [Turcologica 7.1]. Wiesbaden: Harrassowitz

ERdAL, Marcel 2004. A Grammar of Old Turkic [Handbook of Oriental Studies, Section 8 Uralic and Central Asian Studies, Volume 3]. Leiden: Brill.

FAHD, Toufic 2005. 'Magic: Magic in Islam.' In: Jones 2005: Vol. 8, 5583-5587.

FröHlich, Ida 2016. 'Giants and Demons.' In: Matthew Goff, Loren T. Stuckenbruck and Enrico Morano (eds.) Ancient Tales of Giants from Qumran and Turfan: Contexts, Traditions, and Influences. Tübingen: Mohr Siebeck, 97-114.

Furlani, Giuseppe 1917.'A Cosmological Tract by Pseudo-Dionysius in the Syriac Language.' Journal of the Royal Asiatic Society 49/2: 245-272.

Gaster, Theodor H. 2005. 'Amulets and Talismans.' In: Jones 2005: Vol. 1, 297-301.

Geller, M. J. 1997. 'Notes and Communications: More magic spells and formulae.' Bulletin of the School of Oriental and African Studies 60/2: 327-343.

Gieschen, Charles A. 1998. Angelomorphic Christology: Antecedents and Early Evidence [Arbeiten zur Geschichte des antiken Judentums und des Urchristentums 42]. Leiden: Brill.

Goff, Matthew 2014. 'When Giants Dreamed about the Flood: The Book of Giants and its Relationship to the Book of Watchers.' In: Eibert TigchelaAr (ed.) Old Testament Pseudepigrapha and The Scriptures. Leuven: Peeters Press, 61-88.

Goff, Matthew, Loren T. Stuckenbruck and Enrico Morano (eds.) 2016. Ancient Tales of Giants from Qumran and Turfan: Contexts, Traditions, and Influences [Wissenschaftliche Untersuchungen zum Neuen Testament 360]. Tübingen: Mohr Siebeck.

GraF, Georg 1954. Verzeichnis arabischer kirchlicher Termini [Corpus Scriptorum Christianorum Orientalium 147/Subs 8]. Louvain: L. Durbecq.

Gröndahl, Frauke 1967. Die Personennamen der Texte aus Ugarit [Studia Pohl 1]. Rome: Pontifical Biblical Institute.

Harviainen, Tapani 1978. 'A Syriac Incantation Bowl in the Finnish National Museum, Helsinki.' Studia Orientalia 51/1: 1-29. 
Hazard, Willis Hatfield 1893. 'A Syriac Charm.' Journal of the American Oriental Society 15: 284-296.

Henning, W. B. 1936a. 'Neue Materialien zur Geschichte des Manichäismus.' Zeitschrift der Deutschen Morgenländischen Gesellschaft 90: 1-18.

Henning, W. B. 1936b. 'Soghdische Miszellen.' Bulletin of the School of Oriental Studies 8/2-3: 583-588.

Henning, W. B. 1943. 'The Book of the Giants.' Bulletin of the School of Oriental and African Studies 11/1: $52-74$.

Huffmon, Herbert Bardwell 1965. Amorite Personal Names in the Mari Texts: A Structural and Lexical Study. Baltimore: Johns Hopkins Press.

Hunter, Erica C. D. 1987. 'Saints in Syriac Anathemas: A Form-Critical Analysis of Role.' Journal of Semitic Studies 32/1: 83-104.

Hunter, Erica C. D. 1990. ‘Genres of Syriac Amulets: A Study of Cambridge MS. Syr. 3086.' In: René Lavenant (ed.) V Symposium Syriacum, 1988 [Orientalia Christiana Analecta 236]. Rome: Pontificio Institutum Studiorum Orientalium, 355-368.

Hunter, Erica C. D. 1993. 'A Scroll Amulet from Kurdistan.' Aram 5: 243-254.

Hunter, Erica C. D. 1999. 'Another Scroll Amulet from Kurdistan.' In: Gerrit J. ReInink and A. C. KLugkist (eds.) After Bardaisan: Studies in Continuity and Change in Syriac Christianity in Honour of Professor Han J.W. Drijvers [Orientalia Lovaniensia Analecta 89]. Leuven: E. Peeters, 161-172.

Hunter, Erica C. D. 2002. 'Manipulating Incantation Texts: Excursions in Refrain A.' Iraq 64: 259-273.

Hunter, Erica C. D. 2009. 'Magic and Medicine amongst the Christians of Kurdistan.' In: Erica C. D. Hunter (ed.) The Christian Heritage of Iraq [Gorgias Eastern Christian Studies 13]. Piscataway, NJ: Gorgias Press, 187-202.

Hunter, Erica C. D. 2013. 'Traversing Time and Location: A Prayer-Amulet of Mar Tamsis from Turfan.' In: Tang Li and Dietmar W. WinkLer (eds.) From the Oxus River to the Chinese Shores: Studies on East Syriac Christianity in China and Central Asia [Orientalia - Patristica - Oecumenica, Vol. 5]. Wien: LIT Verlag, 25-41.

Hunter, Erica C. D. 2018. 'Syriac Prayer-Amulets from Turfan.' The Harp 33: 413-431.

Hunter, Erica C. D. and Mark Dickens 2014. Syrische Handschriften. Teil 2. Syriac Manuscripts from the Berlin Turfan Collection [Verzeichnis der Orientalischen Handschriften in Deutschland 5,2]. Stuttgart: Franz Steiner.

Inhorn, Marcia C. 2005. 'Healing and Medicine: Popular Healing Practices in Middle Eastern Cultures.' In: JONES 2005: Vol. 6, 3834-3839.

IsBell, Charles D. 1978. 'The Story of the Aramaic Magical Incantation Bowls.' The Biblical Archaeologist 41/1: 5-16.

Jastrow, Marcus 1903. A Dictionary of the Targumim, the Talmud Babli and Yerushalmi, and the Midrashic Literature. London: Luzac and Co.

Jones, Lindsay (ed.-in-chief) 2005. Encyclopedia of Religion. 15 vols. (2nd ed.) Detroit MI: Thomson Gale. Kósa, Gábor 2016. 'The Book of Giants Tradition in the Chinese Manichaica.' In: Goff, Stuckenbruck and Morano 2016: 145-178.

KugeL, James L. 2006. The Ladder of Jacob: Ancient Interpretations of the Biblical Story of Jacob and his Children. Princeton: Princeton University Press.

LEE, Ralph 2014. 'The Ethiopic 'Andəmta' Commentary on Ethiopic Enoch 2 (1 Enoch 6-9).' Journal for the Study of the Pseudepigrapha 23/3: 179-200.

Lin, Lijuan 2020. 'Hippocrates and Galen in Turfan: Remarks on SyrHT 1 and SyrHT 388.' Aramaic Studies 18/2:213-239.

Ludwig, Theodore M. 2005. 'Incantation.' In: Jones 2005: Vol. 7, 4406-4410. 
MAGGI, Mauro 2008. 'Khotan iv. Khotanese Literature'. In: Encyclopcedia Iranica, Online Edition https://iranicaonline.org/articles/khotanese-literature (visited on 22 April, 2021).

Maróth, Miklós 1984. 'Ein Fragment eines syrischen pharmazeutischen Rezeptbuches.' Altorientalische Forschungen 11: 115-125.

Mayer, Gabriele 1996. Und das Leben ist siegreich. Ein Kommentar zu den Kapiteln 18 - 33 des Johannesbuches der Mandäer: Der Traktat über Johannes den Täufer. Dissertation, Ruprecht-Karls-Universität Heidelberg.

Middleton, John 2005. 'Magic: Theories of Magic.' In: Jones 2005: Vol. 8, 5562-5569.

Montgomery, James A. 1918. 'A Syriac Incantation Bowl with Christian Formula'. American Journal of Semitic Languages and Literatures 34/2: 137-139.

Morano, Enrico 2004. 'Manichaean Middle Iranian Incantation Texts from Turfan. In: Desmond DurkinMeisterernst et al. (eds.) Turfan Revisited - The First Century of Research into the Arts and Cultures of the Silk Road. Berlin: Dietrich Reimer Verlag, 221-227.

Morano, Enrico 2009. "If They Had Lived...”: A Sogdian-Parthian Fragment of Mani’s Book of Giants.' In: Werner Sundermann, Almut Hintze and François de Blois (eds.) Exegisti Monumenta: Festschrift in Honour of Nicholas Sims-Williams. Wiesbaden: Harrassowitz, 325-330.

Morano, Enrico 2011. 'New Research on Mani’s Book of Giants.' In: Zekine Özertural and Jens WiLkens (eds.) Der östliche Manichäismus: Gattungs- und Werksgeschichte Vorträge des Göttinger Symposiums vom 4./5. März 2010. Berlin: De Gruyter, 101-112.

Moriggi, Marco 2016. "And the Impure and Abominable Priests Fled for Help to the Names of the Devils": Amulets and Magical Practices in Syriac Christian Culture between Late Antiquity and the Modern World.' Hugoye 19/2: 371-384.

Nieber, Hanna 2017. “"They all just want to get healthy!” Drinking the Qur'an between forming religious and medical subjectivities in Zanzibar.' Journal of Material Culture 22/4: 453-475.

O'Nowlan, T. P. 1905. 'A Prayer to the Archangels for Each Day of the Week.' Ériu 2: 92-94.

Patai, Raphael 2005. 'Folk Religion: Folk Judaism.' In: Jones 2005: Vol. 5, 3157-3161.

Payne Smith, Jessie 1903. A Compendious Syriac Dictionary, founded upon the Thesaurus Syriacus of R. Payne Smith. Oxford: Clarendon Press.

Payne Smith, Robert (ed.) 1879-1901. Thesaurus Syriacus. Oxford: Clarendon.

Pedersen, Nils Arne 2013. 'A Tentative Interpretation of the Texts.' In: Nils Arne Pedersen and John Møller LARSEn (eds.) Manichaean Texts in Syriac: First Editions, New Editions and Studies [Corpus Fontium Manichaeorum: Series Syriaca, Vol. 1]. Turnhout: Brepols, 187-244.

Pedersen, Nils Arne 2017. 'Observations on the Book of the Giants from Coptic and Syriac Sources.' In: Samuel N. C. Liev et al. (eds.) Manichaeism East and West [Corpus Fontium Manichaeorum - Analecta Manichaica, Vol. 1]. Turnhout: Brepols, 185-202.

Piras, Andrea 2005. 'Mani.' In: Jones 2005: Vol. 8, 5646-5650.

Raschmann, Simone-Christiane 2007. Alttürkische Handschriften, Teil 13: Dokumente, Teil 1 [Verzeichnis der Orientalischen Handschriften in Deutschland, 13,21]. Stuttgart: Franz Steiner.

Raschmann, Simone-Christiane 2009. Alttürkische Handschriften, Teil 14: Dokumente, Teil 2 [Verzeichnis der Orientalischen Handschriften in Deutschland, 13,22]. Stuttgart: Franz Steiner.

Raschmann, Simone-Christiane and Osman Fikri Sertkaya 2016. Alttürkische Handschriften, Teil 20: Alttürkische Texte aus der Berliner Turfansammlung im Nachlass Reșid Rahmeti Arat [Verzeichnis der Orientalischen Handschriften in Deutschland, 13,28]. Stuttgart: Franz Steiner. 
Reck, Christiane 2018. Mitteliranische Handschriften, Teil 3: Berliner Turfanfragmente christlichen Inhalts und Varia in soghdischer Schrift [Verzeichnis der Orientalischen Handschriften in Deutschland, 18,3]. Stuttgart: Franz Steiner.

Reed, Annettte Y. 2004. 'Heavenly Ascent, Angelic Descent, and the Transmission of Knowledge in 1 Enoch 6-16.' In: Ra'anan S. Boustan and Annette Y. Reed (eds.) Heavenly Realms and Earthly Realities in Late Antique Religions. Cambridge: Cambridge University Press, 47-66.

ReED, Annette Y. 2005a. 'Interrogating "Enochic Judaism”: 1 Enoch as Evidence for Intellectual History, Social Realities, and Literary Tradition.' In: Gabriele Boccaccini (ed.) Enoch and Qumran Origins: New Light on a Forgotten Connection. Grand Rapids: Eerdmans, 336-344.

ReEd, Annette Y. 2005b. “"Revealed Literature” in the Second Century BCE: Jubilees, 1 Enoch, Qumran, and the Prehistory of the Biblical Canon. In: Gabriele Boccaccini (ed.) Enoch and Qumran Origins: New Light on a Forgotten Connection. Grand Rapids: Eerdmans, 94-98.

Reed, Annette Y. 2009. 'The Modern Invention of "Old Testament Pseudepigrapha”. Journal of Theological Studies 60/2: 403-436.

ReEd, Annette Y. 2016. 'Enoch, Eden, and the Beginnings of Jewish Cosmography' In: Charles Burnett and Jill Kraye (eds.) Enoch, Eden, and the Beginnings of Jewish Cosmography. London: Warburg Institute Colloquia, 67-94.

Reeves, John C. 1991. 'An Enochic Motif in Manichaean Tradition. In: Alois van Tongerloo and Soren Giversen (eds.) Manichaica Selecta: Studies Presented to Professor Julien Ries on the Occasion of his Seventieth Birthday. Louvain: International Association of Manichaean Studies, 295-298.

Reeves, John C. 1994. 'Jewish Pseudepigrapha in Manichaean Literature: The Influence of the Enochic Library.' In: John C. Reeves (ed.) Tracing the Threads: Studies in the Vitality of Jewish Pseudepigrapha. Atlanta, GA: Scholars Press, 173-203.

ReEves, John C. 1997. 'Manichaean Citations from the Prose Refutations of Ephrem.' In: Paul Mirecki and Jason BeDunn (eds.) Emerging from Darkness: Studies in the Recovery of Manichaean Sources. Leiden: Brill, 217-288.

Reeves, John C. 2016. 'Jacob of Edessa and the Manichaean Book of Giants?' In: Goff, Stuckenbruck and Morano 2016: 199-211.

RuAnI, Flavia 2013. 'Between Myth and Exegesis: Ephrem the Syrian on the Manichaean Book of Giants.' In: Markus Vinzent (ed.) Studia Patristica LXIV, Vol. 12: Ascetica, Liturgica, Orientalia, Critica et Philologica. Leuven: Peeters, 155-165.

van RuITEN, J.T.A.G.M. 2000. Primaeval history interpreted: the rewriting of Genesis I-II in the book of Jubilees [Supplements to the Journal for the study of Judaism 66]. Leiden: Brill.

Schniedewind, William M. and Bruce Zuckerman 2001. 'A Possible Reconstruction of the Name of Haza'el's Father in the Tel Dan Inscription.' Israel Exploration Journal 51/1: 88-91.

Sсншав, Moїse 1897. Vocabulaire de langélologie, d’après les manuscrits hébreux de la Bibliothèque nationale. Paris: Imprimerie Nationale.

Segal, J. B. and Erica C. D. Hunter 2000. Catalogue of the Aramaic and Mandaic Incantation Bowls in the British Museum. London: British Museum Press.

SEGAL, Michael 2007. The Book of Jubilees. [Supplements to the Journal for the Study of Judaism 117]. Leiden and Boston: Brill.

Sims-Williams, Nicholas 1989. 'Bulayïq.' In: Ehsan Yarshater (ed.) Encyclopaedia Iranica. Vol. 4. London and Boston: Routledge \& Kegan Paul, 545. 
Sims-Williams, Nicholas 2003. 'A Christian Sogdian polemic against the Manichaeans.' In: Carlo G. Cereti, Mauro Maggi and Elio Provasi (eds.) Religious Themes and Texts of Pre-Islamic Iran and Central Asia [Beiträge zur Iranistik 24]. Wiesbaden: Dr. Ludwig Reichert Verlag, 399-408.

Sims-Williams, Nicholas 2011. 'Early New Persian in Syriac script: Two texts from Turfan.' Bulletin of the School of Oriental and African Studies 74/3: 353-374.

Sims-Williams, Nicholas 2012. Mitteliranische Handschriften: Teil 4. Iranian Manuscripts in Syriac Script in the Berlin Turfan Collection [Verzeichnis der Orientalischen Handschriften in Deutschland 18,4]. Stuttgart: Franz Steiner.

Sims-Williams, Nicholas 2013. 'Medical texts from Turfan in Syriac and New Persian. In: Xinjiang Tulufanxue yanjiuyuan 新疆吐鲁番学研究院 [Academia Turfanica] (ed.) Yuyan beihou de lishi: xiyu gudian yuyanxue gaofeng luntan lunwenji 语言背后的历史 - 西域古典语言学高峰论坛论文集 [The History behind the Languages. Essays of Turfan Forum on Old Languages of the Silk Road]. Shanghai: Shanghai guji chubanshe, 12-19.

Sims-Williams, Nicholas 2020. 'The Sogdian "Book of Life" Reconsidered.' In: Tang Li and Dietmar W. Winkler (eds.) Artifact, Text, Context: Studies on Syriac Christianity in China and Central Asia [Orientalia - Patristica - Oecumenica, Vol. 17]. Wien: LIT Verlag, 113-119.

SoкоLoff, Michael 2009. A Syriac Lexicon: A Translation from the Latin, Correction, Expansion, and Update of C. Brockelmann's Lexicon Syriacum. Winona Lake, IN; Piscataway, NJ: Eisenbrauns; Gorgias Press.

Stone, Michael E. 1991. Selected Studies in Pseudepigrapha and Apocrypha: With Special Reference to the Armenian Tradition. Leiden: E. J. Brill.

Stuckenbruck, Loren T. 2016. 'The Book of Giants among the Dead Sea Scrolls: Considerations of Method and a New Proposal on the Reconstruction of 4Q530.' In: Goff, STuckenbruck and Morano 2016: 129-139.

Sundermann, Werner 1973. Mittelpersische und parthische kosmogonische und Parabeltexte der Manichäer [Berliner Turfantexte IV]. Berlin: Akademie Verlag.

Sundermann, Werner 2009. 'Ein manichäischer Traktat über und wider die Christen.' In: Werner Sundermann, Almut Hintze and François De Blois (ed.) Exegisti Monumenta: Festschrift in Honour of Nicholas Sims-Williams. Wiesbaden: Harrassowitz, 497-508.

Tekin, Talat 1968. A Grammar of Orkhon Turkic [Indiana University Publications, Uralic and Altaic Series, Vol. 69]. Bloomington: Indiana University.

Tekin, Talat 1994. 'Notes on Old Turkic Word Formation.' Central Asiatic Journal 38/2: 244-281.

Tuschling, R. M. M. 2007. Angels and Orthodoxy: a Study in their Development in Syria and Palestine from the Qumran Texts to Ephrem the Syrian [Studien und Texte zu Antike und Christentum 40]. Tübingen: Mohr Siebeck.

VAn Rompay, Lucas 1990. 'Some Remarks on the Language of Syriac Incantation Texts'. In: René Lavenant (ed.) V Symposium Syriacum, 1988 [Orientalia Christiana Analecta 236]. Rome: Pontificio Institutum Studiorum Orientalium, 369-381.

VanderKam, James C. 1996. '1 Enoch, Enochic Motifs, and Enoch in Early Christian Literature.' In: James C. VANDerKam and William Adler (eds.) The Jewish Apocalyptic Heritage in Early Christianity [Compendia Rerum Iudaicarum ad Novum Testamentum 3/4]. Leiden: Brill, 33-101.

VanderKam, James C. 2001. The Book of Jubilees. Sheffield: Sheffield Academic Press.

Wilkens, Jens 2016. 'Remarks on the Manichaean Book of Giants: Once Again on Mahaway's Mission to Enoch.' In: Goff, StUCKenbruck and Morano 2016: 213-229. 
Wilkens, Jens 2018. 'The Old Uygur Version of the Manichaean Book of Giants and Its Context.' In: Zsuzsanna Gulácsi (ed.) Language, Society, and Religion in the World of the Turks: Festschrift for Larry Clark at Seventy-Five [Silk Road Studies XIX]. Turnhout: Brepols, 281-299.

WRIGHT, William 1901. A catalogue of the Syriac manuscripts preserved in the library of the University of Cambridge, Vol. I. Cambridge: Cambridge University Press.

YAmauCHI, Edwin M. 1965. 'Aramaic Magic Bowls'. Journal of the American Oriental Society 85/4: 511-523.

ZIEME, Peter 1997/1998. 'Das nestorianische Glaubensbekenntnis in einem alttürkischen Fragment aus Bulayiq.' Ural-Altaische Jahrbücher 15 (N.F.): 173-180.

Zieme, Peter 2002. 'Türkische Zuckungsbücher'. In: Ingeborg Hauenschild, Claus Schönig and Peter ZieME (eds.) Scripta Ottomanica et Res Altaicae. Festschrift Barbara Kellner-Heinkele [Veröffentlichungen der Societas Uralo-Altaica 56]. Wiesbaden: Harrassowitz Verlag, 379-395.

Zieme, Peter 2015. Altuigurische Texte der Kirche des Ostens aus Zentralasien [Gorgias Eastern Christian Studies 41]. Piscataway, NJ: Gorgias Press. 